\title{
Investor-State Dispute Settlement Reform: Reconsidering the Multilateral Investment Court in the Context of Disputes Involving Intellectual Property Law
}

\author{
Mary Zhao*
}

\begin{abstract}
On January 18, 2019, the European Commission submitted a proposal to the United Nations Commission on International Trade Law to establish a multilateral investment court for investor-state disputes. The European Commission's proposal reflects growing discussions about the potential reform of the investor-state dispute settlement system. While the present work on reform options focuses on issues relating to the legitimacy of the investor-state dispute settlement system, the effects of the reform options on investor-state disputes that specifically involve intellectual property law remain to be examined.

This Article argues that although the proposed multilateral court structure offers a comprehensive approach to addressing the concerns with the investor-state dispute settlement system, it does not address a number of issues that are specific to disputes involving intellectual property law. This Article analyzes issues that arise from the arbitral tribunal's role in investor-state disputes that involve laws governing intellectual property at the international and domestic levels. In doing so, this Article shows that these issues are distinct from the ones that broadly relate to the legitimacy of the investor-state dispute settlement system. In light of these issues, this Article proposes additional considerations for the multilateral investment court structure. Specifically, this Article proposes including expertise in the relevant international agreements as a selection criteria for adjudicators and giving deference to the host state's courts in disputes that involve issues of domestic intellectual property law.
\end{abstract}

* J.D. (2018), Stanford University; graduate fellow (2018), Stanford Center on International Conflict and Negotiation. I am grateful to my professors for their encouragement and inspiration.

(C) 2021 Zhao. This is an open access article distributed under the terms of the Creative Commons Attribution License, which permits unrestricted use, distribution, and reproduction, provided the original author and source are credited. 
TABLE OF CONTENTS

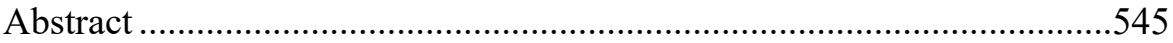

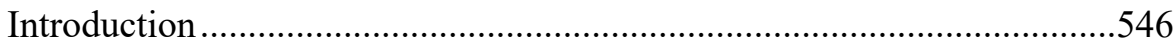

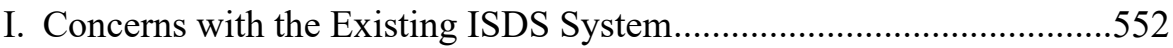

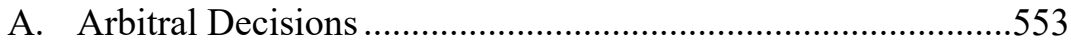

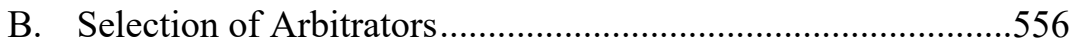

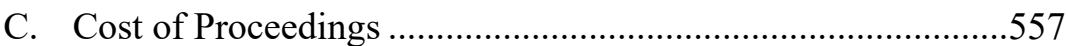

II. Potential Reform of the ISDS System ...............................................558

A. UNCITRAL's Work in Developing Reform Solutions..............559

B. The European Commission's Proposal for a Multilateral Investment Court.......................................................................561

III. ISDS as a Forum for Enforcing States' Intellectual Property

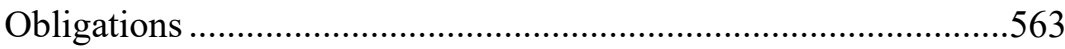

A. The Investor's Intellectual Property Rights in the Host State...565

B. The Host State's International Intellectual Property

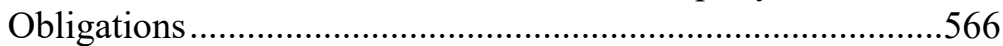

C. Safeguard Provisions ..............................................................567

IV. Issues Specific To Investor-State Disputes Involving Intellectual

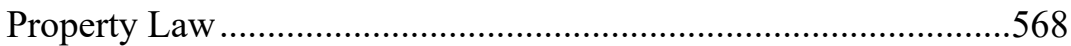

A. Application of the Intellectual Property Rules From International

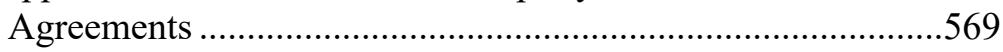

B. Application of Domestic Intellectual Property Law..................572

C. Regulatory Space for Domestic Intellectual Property Policy ....575

V. Conclusion

\section{INTRODUCTION}

The United Nations Commission on International Trade Law (UNCITRAL) ${ }^{1}$ Working Group III entered into the final phase of its work on the possible reform of the current investor-state dispute settlement (ISDS) system in October 2019. ${ }^{2}$ The

1. The United Nations General Assembly established UNCITRAL in 1966 with the mandate to pursue the progressive harmonization and unification of international trade law. G.A. Res. 2205 (XXI), at 2 (Dec. 17, 1966) [hereinafter G.A. Res. 2205 (XXI)]. International trade law refers to "the body of rules governing commercial relationships of a private law nature involving different countries." U.N. GAOR, 21st Sess., 1497th plen. mtg. ๆ 10, U.N. Doc A/6396 (Sept. 23, 1966) [hereinafter U.N. Doc $\mathrm{A} / 6396]$.

2. U.N. Comm'n on Int'l Trade Law, Rep. of Working Grp. III on the Work of Its Thirty-Eighth Session, U.N. Doc. A/CN.9/1004, 27 (2019) [hereinafter U.N. Doc. A/CN.9/1004]. Fifty-four member states attended the thirty-eighth session of Working Group III, the session in which the Working Group began the final phase of its mandate. Id. $\uparrow$ 5. See also U.N. Comm'n on Int'1 Trade Law, Rep. of Working Grp. III on the Work of Its Thirty-Seventh Session, U.N. Doc. A/CN.9/970, ๆ甲 80-85 (2019) [hereinafter U.N. Doc. A/CN.9/970]. Working Group III consists of all of the member states of the UNCITRAL 
Working Group undertook this work in response to growing concerns among scholars and international bodies about the legitimacy of the ISDS system. ${ }^{3}$ In 2017 , at its fiftieth session, the UNCITRAL Commission entrusted Working Group III with the broad mandate to work on the potential reform of the ISDS system. ${ }^{4}$ After the UNCITRAL member states reached consensus on the fact that concerns relating to the current ISDS system exist and that reform is desirable, the Working Group began the final phase of its mandate, which is to develop relevant solutions in light of the identified concerns. $^{5}$

The current ISDS system consists of over 3,000 international investment agreements $^{6}$ that are instruments of public international law. ${ }^{7}$ These agreements were initially conceived to enhance confidence in the host state's investment environment by providing substantive guarantees to foreign investors in the form of enforceable obligations on the host state. $^{8}$ In this way, the treaties aimed to encourage investment in the host state by protecting foreign investors from certain risks. Early international investment agreements aimed to facilitate a stable investment environment in developing countries, in turn helping the developing countries attract funds from foreign investors. ${ }^{9}$

Commission. U.N. Comm'n on Int'l Trade Law, Rep. of Working Grp. III on the Work of Its ThirtySixth Session, U.N. Doc. A/CN.9/964, 96 (2018) [hereinafter U.N. Doc. A/CN.9/964].

3. U.N. Comm'n on Int'l Trade Law, Possible Future Work in the Field of Dispute Settlement: Reforms of Investor-State Dispute Settlement (ISDS), U.N. Doc. A/CN.9/917, ףף 12-16 (2017) [hereinafter U.N. Doc. A/CN.9/917]. Legitimacy in the context of the ISDS system refers to people's willingness to accept the legal order, in particular as to having individual arbitrators assess the validity of state actions. Gabriel Bottini, Reform of the Investor-State Arbitration Regime: The Appeal Proposal, in Reshaping the InVestor-State Dispute Settlement System 455, 464 (Jean E. Kalicki \& Anna Joubin-Bret eds., 2015).

4. U.N. Doc. A/CN.9/1004, supra note 2, 9 2; U.N. Doc. A/CN.9/917, supra note 3, q币 1-8, 6769; U.N. Doc. A/CN.9/970, supra note 2, ๆ 1.

5. U.N. Doc. A/CN.9/1004, supra note 2, $\uparrow \uparrow \mid 2,15$.

6. U.N. CONF. ON TRADE \& DEV., WORLD INVESTMENT REPORT 2015: REFORMING INTERNATIONAL INVESTMENT GOVERNANCE, at 124, U.N. Doc. UNCTAD/WIR/2015, U.N. Sales No. E.15.II.D.5 (2015) [hereinafter World Investment Report 2015]. International investment agreements refer to any bilateral or multilateral treaty that contains provisions on the protection of investments or investors, including any free trade agreements, economic integration agreements, trade and investment frameworks, and cooperation agreements. U.N. Comm'n on Int'l Trade Law, Possible Reform of Investor-State Dispute Settlement (ISDS), U.N. Doc. A/CN.9/WG.III/WP.149, at 2 n.3 (2018) [hereinafter U.N. Doc. A/CN.9/WG.III/WP.149].

7. U.N. Doc. A/CN.9/WG.III/WP.149, supra note 6, 94.

8. Id.; see also DAVID E. O'CONNOR, 1 ENCYClOPEDIA OF THE Global ECONOMY: A Guide FOR STUDENTS AND RESEARCHERS 239 (2006) (defining International Investment Agreements).

9. See Gabrielle Kaufmann-Kohler \& Michele Potestà, Can the Mauritius Convention Serve as a Model for the Reform of Investor-State Arbitration in Connection with the Introduction of a Permanent Investment Tribunal or an Appeal Mechanism?, CIDS—GENEVA CTR. FOR INT'L DISP. SETTLEMENT 7-8 (2016), https://perma.cc/BPA3-VNRR; see also World Investment Report 2015, supra note 6, at 125 (noting the potential of international investment agreements to facilitate cross-border investment as part of broader economic integration agendas for achieving sustainable development goals). Developing countries are increasingly becoming the source of large investments themselves, with one third of the world's FDI outflow coming from emerging economies. Id. at 127. 
Bilateral investment treaties (BITs) are one of the most common forms of international investment agreements. ${ }^{10}$ The Germany-Pakistan BIT of 1959 is the first BIT. ${ }^{11}$ It follows the spirit of existing bilateral treaties of friendship and commerce that states concluded during the inter-war and post-World War II era. The BITs that states concluded in the period from the end of World War II until the mid1960s focused on protecting foreign investors from expropriation and nationalization. ${ }^{12}$ With the fall of the Berlin Wall in 1989, the dissolution of the Soviet Union in 1991, and China's "Open Door" policy in the 1980s and 1990s, the number of BITs grew rapidly during the turn of the century. ${ }^{13}$ The total number of BITs reached over 2,000 by the end of year $2000 .{ }^{14}$ The increase in the number of BITs occurred in parallel with the rise of regional establishments such as the North American Free Trade Agreement (NAFTA) in 1992, the founding of the World Trade Organization (WTO) in 1994, and the conclusion of the Energy Charter Treaty in the same year. ${ }^{15}$

Bilateral investment treaties allow a foreign investor to bring a claim in ISDS directly against the host state in which the investor has investments. ${ }^{16}$ The state's signature to the treaty represents the state's consent to the investor-state arbitral process. ${ }^{17}$ Although the provisions in different treaties vary, the substantive provisions governing ISDS in each treaty generally provide foreign investors with a guarantee of fair and equitable treatment, compensation for the expropriation of investments, compensation for unreasonable or discriminatory state measures, and a guarantee of favorable treatment equal to that of domestic investors. ${ }^{18}$ The procedural provisions generally provide for an ad hoc arbitral tribunal ${ }^{19}$ to hear disputes arising from the treaty and for both the investor claimant and the respondent host state to have a role in selecting the arbitral tribunal. ${ }^{20}$

By allowing a private entity to file a claim against a sovereign, ISDS marks a significant break from the traditional mechanism of enforcement under international law. ${ }^{21}$ Prior to the creation of investment treaties and the ISDS system, investors

\footnotetext{
10. O'CONNOR, supra note 8, at 239.

11. World Investment Report 2015, supra note 6, at 122.

12. Id.

13. Id. at 123; Guocang Huan, China's Open Door Policy, 1978-1984, 39 J. INT'L AFF. 1, 1 (1986).

14. World Investment Report 2015, supra note 6, at 123.

15. $I d$.

16. See U.N. Doc. A/CN.9/WG.III/WP.149, supra note 6, ๆ 5; Kaufmann-Kohler \& Potestà, supra note 9, at 6; GARY B. BORn, INTERNATIONAL ARBitration: LAW AND PRACTICE 7-9 (2d ed. 2015) (noting that international arbitration is a commonly preferred means of resolving investor-state disputes).

17. See Cynthia M. Ho, Sovereignty Under Siege: Corporate Challenges to Domestic Intellectual Property Decisions, 30 BERKELEY TECH. L.J. 213, 232 (2015).

18. Id. at 231-32; U.N. Doc. A/CN.9/WG.III/WP.149, supra note 6, $₫ 6$.

19. Ad hoc arbitral tribunal refers to an arbitral tribunal that is constituted for the purpose of hearing a particular dispute. Kaufmann-Kohler \& Potestà, supra note 9, at 6.

20. Id.

21. See U.N. Doc. A/CN.9/WG.III/WP.149, supra note 6, 95.
} 
either relied on state diplomacy ${ }^{22}$ or on the host state's domestic courts. ${ }^{23}$ These options gave investors limited avenues to seek relief because the investor's home state may be unwilling to take diplomatic measures and the host state's domestic courts may have a bias against foreigners. ${ }^{24}$ Some scholars have commented that ISDS contributed to enhancing the rule of law at the international level by depoliticizing investment disputes and reducing the risk that such disputes escalate into inter-state conflicts. ${ }^{25}$

The ISDS system gives intellectual property right holders an unprecedented opportunity to directly challenge a host state's compliance with its international intellectual property obligations, such as those under the Agreement on TradeRelated Aspects of Intellectual Property Rights (TRIPS) and the intellectual property chapter of NAFTA. ${ }^{26}$ In the traditional legal framework, private right holders have no standing to challenge the host state's compliance with international intellectual property norms. ${ }^{27}$ The obligations that states undertake in the intellectual property chapters of free trade agreements are vis-à-vis other member states, rather than private investors. ${ }^{28}$ The WTO dispute settlement system, for example, only allows states to challenge the measures. Also, domestic courts seldom allow private parties to invoke international intellectual property norms in challenging domestic intellectual property provisions. ${ }^{29}$ With the emergence of ISDS as a forum for private parties to challenge state measures, host states face challenges to their intellectual property policies from foreign investors. ${ }^{30}$ In 2017, the tribunal in Eli Lilly v. Canada issued the first final decision involving the intersection of international investment law and patent law. ${ }^{31}$

22. State diplomatic protection refers to the "invocation by a State, through diplomatic action or other means of peaceful settlement, of the responsibility of another State for an injury caused by an internationally wrongful act of that State to a natural or legal person that is a national of the former State with a view to the implementation of such responsibility." Int'l Law Comm'n, Rep. on the Work of Its Fifty-Eight Session, U.N. Doc. A/61/10, at 24 (2006) [hereinafter U.N. Doc. A/61/10].

23. Ho, supra note 17 , at 232 .

24. Id.

25. Kaufmann-Kohler \& Potestà, supra note 9 , at 8.

26. See Henning Grosse Ruse-Khan, Challenging Compliance with International Intellectual Property Norms in Investor-State Dispute Settlement, 19 J. INT'L ECON. L. 241, 241-42 (2016).

27. See id. at 242; see also Ho, supra note 17, at 219-20 (noting that investment treaty protection may be a "new way forward" for multinational pharmaceutical companies to seek patent protection); James Gathii \& Cynthia Ho, Regime Shifting of IP Lawmaking and Enforcement from the WTO To the International Investment Regime, 18 MiNN. J.L. SCI. \& TECH. 427, 428-29 (2017).

28. Kathleen Liddell \& Michael Waibel, Fair and Equitable Treatment and Judicial Patent Decisions, Paper No. 4/2016, U. CAMBridge Legal Stud. RsCh. PAPER Series, 26 n.94 (2016).

29. Grosse Ruse-Khan, supra note 26, at 242.

30. Ho, supra note 17 , at 222.

31. Eli Lilly \& Co. v. Canada, ICSID Case No. UNCT/14/2, Final Award (Mar. 16, 2017) [hereinafter Eli Lilly Final Award]; Gabriel M. Lentner, Litigating Patents in Investment Arbitration: Eli Lilly v. Canada, 12 J. INTELL. PROP. L. \& PRAC. 815, 815 (2017). In 2012, Eli Lilly filed the first ISDS dispute alleging the breach of intellectual property rights under a United States free trade agreement. Eli Lilly challenged Canada's promise doctrine, which was a well-established patent rule in Canada that served as one of the patentability standards, under the NAFTA investment clause. Brook K. Baker, Corporate Power Unbound: Investor-State Arbitration of IP Monopolies on Medicines-Eli Lilly and the TPP, Paper 36, JOINT PIJIP/TLS RSCH. PAPER SERIES, at 5 (2013). 
In recent years, discussions among scholars and international bodies have emphasized concerns about the legitimacy of the present ISDS system. ${ }^{32}$ The power that investment treaties grant to tribunals in deciding disputes involving public issues has raised concerns about the democratic accountability of the ISDS system. ${ }^{33}$ Concerns include individual arbitrators' potential lack of independence and impartiality, inconsistencies in tribunals' interpretations of treaty provisions, and a lack of transparency in the arbitral process. ${ }^{34}$ Further, the broad language of investment treaties has sometimes resulted in unanticipated and inconsistent interpretations, generating uncertainty about the obligations that the treaties impose on states. ${ }^{35}$ The former European Commissioner for Trade, Cecilia Malmström, noted a "fundamental and widespread lack of trust by the public in the fairness and impartiality" of the ISDS system. ${ }^{36}$ In light of these concerns, some states renegotiated the provisions of their existing investment treaties. ${ }^{37}$

The emerging view is that the ISDS system is in need of reform. ${ }^{38}$ International bodies have discussed various proposals for reform. At the center of such discussions is the proposal to create a multilateral adjudicatory body for investor-state disputes, either in the form of an appeal mechanism or in the form of a permanent investment court that would replace the current ISDS system. ${ }^{39}$ Most recently, the European Commission set forth such a proposal in its submission to UNCITRAL Working Group III in 2019, as the Working Group began the final phase of its work on the potential reform of the ISDS system. ${ }^{40}$

Despite growing discussions about the multilateral reform of the ISDS system, the potential impact of such reform on disputes that involve the host state's intellectual property obligations remains to be examined. This is in part because the intersection of investment arbitration with intellectual property law is a recent

32. Kaufmann-Kohler \& Potestà, supra note 9 , at 14

33. Id.

34. Id. at 11-14.

35. World Investment Report 2015, supra note 6, at 125-26.

36. Cecilia Malmström, Proposing an Investor Court System, EuR. CoMM’N (Sept. 16, 2015), https://perma.cc/ADV4-6KHG.

37. Australia issued a statement in April 2011 that set forth its decision to no longer include investor-state arbitration as a remedy in future trade agreements with developing countries. Germany withdrew formal support for the ISDS provision in the Transatlantic Trade and Investment Partnership Agreement. See Ho, supra note 17, at 220; Ruth L. Okediji, Is Intellectual Property "Investment"? Eli Lilly v. Canada and the International Intellectual Property System, 35 U. PA. J. INT’L L. 1121, 1132 (2014); Eduardo Zuleta, The Challenges of Creating a Standing International Investment Court, in ReShAPING THE INVESTOR-StATE DisPute SetTlement SyStem 403, 407 n.18 (Jean E. Kalicki \& Anna Joubin-Bret eds., 2015). Ecuador, Venezuela, Indonesia, and South Africa terminated a number of BITs in the past decade. See Kaufmann-Kohler \& Potestà, supra note 9, at 10. Bolivia, Ecuador, and Venezuela denounced the ICSID Convention and worked to create a new regional center under the auspices of the Union of South American Nations for resolving investor-state disputes. See Zuleta, supra, at 406-07.

38. World Investment Report 2015, supra note 6, at 120.

39. Id. (noting the importance of adopting a multilateral approach toward the reform of international investment agreements); see also Kaufmann-Kohler \& Potestà, supra note 9, at 16.

40. U.N. Comm'n on Int'l Trade Law, Possible Reform of Investor-State Dispute Settlement (ISDS): Submission from the European Union and Its Member States, U.N. Doc. A/CN.9/WG.III/WP.159, 甲ๆ 1-6 (2019) [hereinafter U.N. Doc. A/CN.9/WG.III/WP.159]. 
development. $^{41}$ Discussions about reform plans have focused on analyzing the effectiveness of the reform plans for addressing concerns with the legitimacy of the ISDS system in general, rather than focusing on investor-state disputes that involve intellectual property law. ${ }^{42}$ Past work on the intersection of investment arbitration and intellectual property law suggests that investor-state disputes that involve intellectual property law present a unique set of issues that are distinct from the concerns relating broadly to the legitimacy of the ISDS system. ${ }^{43}$

This Article analyzes the extent to which a multilateral permanent adjudicatory body such as that proposed by the European Commission may effectively address issues that are specific to investor-state disputes that involve intellectual property law. This Article examines the issues that may arise from the arbitral tribunal's role in disputes that involve laws governing intellectual property at the international and domestic levels. In doing so, this Article shows that, while the proposed multilateral permanent adjudicatory body offers a comprehensive approach for addressing the legitimacy concerns with the ISDS system in general, it does not address a number of issues that are specific to disputes involving the host state's intellectual property obligations. Taking these issues into consideration, this Article proposes including expertise in the relevant international agreements that govern intellectual property as a criterion for selecting adjudicators, as well as giving deference to the host state's courts in disputes that involve issues of domestic intellectual property law.

Part I examines the concerns that have been at the center of discussions about reforming the present ISDS system. It discusses the three categories of concerns that UNCITRAL Working Group III identified in its work on the potential reform of the ISDS system: concerns relating to (1) arbitral decisions; (2) the selection of arbitrators; and (3) the cost of proceedings. This Part shows that the concerns are interlinked across the three categories and that they all broadly relate to the legitimacy of the ISDS system.

Part II focuses on the European Commission's submission to UNCITRAL Working Group III in 2019 of a reform plan for establishing a multilateral investment court with two tiers of review. This Part first sets forth the process of UNCITRAL's work and the context in which the European Commission submitted its reform proposal. It then details the structure of the proposed multilateral investment court.

41. Okediji, supra note 37 , at 1122 .

42. U.N. Doc. A/CN.9/964, supra note 2, - 22; Anthea Roberts, Incremental, Systemic, and Paradigmatic Reform of Investor-State Arbitration, 112 AM. J. INT'L L. 410, 414-17 (2018) (noting that both actual and perceived issues with the investor-state dispute settlement system matter because states need to consider the public's perception of the system).

43. See Grosse Ruse-Khan, supra note 26, at 261-73 (discussing the interpretation of international intellectual norms in investment arbitration); Ho, supra note 17, at 215-25 (discussing the impact of investor-state disputes on states' regulatory space); Liddell \& Waibel, supra note 28, at 1-6 (discussing tensions between the scope of states' obligations under investment treaties and domestic courts' interpretation of domestic patent law); Okediji, supra note 37, at 1132 (discussing the potential effects of resolving investor-state arbitration disputes that involve the intellectual property provisions of the Agreement on Trade-Related Aspects of Intellectual Property Rights); see also Baker, supra note 31, at 2-6 (discussing the impact of investor-state disputes on the public's access to medicines). 
Part III discusses the fair and equitable standard provision as one possible avenue by which investors may seek to enforce a host state's intellectual property obligations. In doing so, this Part shows that it is possible for investors as private parties to enforce the host state's intellectual property obligations in ISDS.

Part IV considers the issues that may arise from the arbitral tribunal's role in disputes that involve laws governing intellectual property at the international and domestic levels. It shows that these issues are separate from the ones that have been at the center of discussions about possible reform of the ISDS system. It suggests that, although the proposed multilateral investment court addresses the concerns that Working Group III identified during its deliberations, the proposal does not address a number of issues that are specific to disputes involving intellectual property law.

\section{CONCERNS WITH THE EXISTING ISDS SYSTEM}

In 2017, at the Commission's fiftieth session, the UNCITRAL Commission entrusted UNCITRAL Working Group III with the broad mandate to work on the possible reform of the ISDS system. ${ }^{44}$ The Working Group was to proceed with discharging the mandate in three phases: (1) identifying concerns with the existing ISDS system; (2) considering whether reform is desirable in light of the identified concerns, if any; and (3) developing relevant solutions for reforming the system, if necessary. ${ }^{45}$ In discharging its mandate, the Working Group was to take into consideration the work of relevant international organizations and allow each member state to choose whether and to what extent they shall adopt any relevant solutions. ${ }^{46}$ At its working sessions, the Working Group emphasized the need to consider reform at the multilateral level and to balance the rights of investors with those of the host state. ${ }^{47}$

In completing the first two phases of the Working Group's mandate, states expressed the view that reform of the existing ISDS system is desirable. ${ }^{48}$ States noted that investment policies should provide certainty, dispute settlement procedures should be fair and transparent, and a balance should exist between the rights of the host state and the rights of the investor. ${ }^{49}$ Some states commented that a comprehensive reform of the ISDS system at the multilateral level may allow states to conclude investment treaties without having to include an ISDS provision in the

44. U.N. Doc. A/CN.9/970, supra note 2, $₫ 1$.

45. Id. The Working Group has focused its work on addressing the procedural aspects of ISDS, while at the same time taking note of possible interactions between the procedural aspects and the substantive standards of investment agreements. Id. $\uparrow 27$. The Working Group noted that options outside of international arbitration, such as local remedies, may address some of the concerns with the ISDS system. Id. ๆๆ $27-30$.

46. Id. 91 .

47. U.N. Doc. A/CN.9/964, supra note 2, If 16 ("[A]ny dispute settlement regime should appropriately address the rights and obligations of foreign investors and ... the right to regulate and the flexibility of States to protect legitimate public welfare objectives should be respected.").

48. U.N. Comm'n on Int'l Trade Law, Possible Reform of Investor-State Dispute Settlement (ISDS): Submission from the Government of Morocco, U.N. Doc. A/CN.9/WG.III/WP.161, ๆ 2 (2019) [hereinafter U.N. Doc. A/CN.9/WG.III/WP.161].

49. See U.N. Doc. A/CN.9/WG.III/WP.149, supra note 6, १ๆ 21-22. 
treaty. ${ }^{50}$ Other states expressed the view that ISDS reform would facilitate responsible international investment for achieving the 2030 Agenda for the Sustainable Development Goals. ${ }^{51}$

The member states of Working Group III identified a number of issues with the existing ISDS system. These issues fall under three broad categories: (1) issues relating to arbitral decisions' "lack of consistency, coherence, predictability, and correctness"; (2) issues relating to arbitrators; and (3) issues relating to the cost and duration of disputes. ${ }^{52}$ Working Group III noted that these three categories all broadly relate to the nature of ISDS as an instrument of public international law, as bilateral investment treaties are fundamentally treaties between two sovereigns. ${ }^{53}$ The obligations that the treaties impose on states thus imply a balance between the need to protect investors from certain state conduct and the host state's right to implement regulations in the interest of its citizens. ${ }^{54}$ This Part analyzes the manner in which the issues in each of the three categories arise in investor-state disputes and the ways in which the issues are interlinked.

\section{A. Arbitral Decisions}

Issues relating to arbitral decisions concern two aspects of the decisions: consistency and correctness. States were of the view that ensuring the correctness of decisions would generally assist in achieving consistency. ${ }^{55}$ In considering reform options, the Working Group took note of the need to find a balance between enhancing the correctness of the decision-making process and the need for an efficient and final dispute settlement process. ${ }^{56}$

The first area of concern is the lack of consistency in arbitral decisions. ${ }^{57}$ Inconsistencies generally arise in three scenarios. ${ }^{58}$ First, tribunals have reached divergent conclusions in disputes involving similar facts that arise from the same

50. U.N. Doc. A/CN.9/WG.III/WP.161, supra note 48, 93.

51. Id. $₫ 4$.

52. U.N. Doc. A/CN.9/964, supra note 2, ๆ 22.

53. U.N. Comm'n on Int'l Trade Law, Possible Reform of Investor-State Dispute Settlement (ISDS): Submission from the European Union, U.N. Doc. A/CN.9/WG.III/WP.145, ๆ 3 3-4 (2017) [hereinafter U.N. Doc. A/CN.9/WG.III/WP.145].

54. Id. 9 . Investor-state disputes often involve questions of public policy, which some scholars have noted as a point of distinction between investor-state arbitration and commercial arbitration. Id. $\uparrow$ 21; see also U.N. Comm'n on Int'l Trade Law, Possible Reform of Investor-State Dispute Settlement (ISDS): Submission from the Government of Thailand, U.N. Doc. A/CN.9/WG.III/WP.162, ๆ $5-14$ (2019) [hereinafter U.N. Doc. A/CN.9/WG.III/WP.162]. The adjudicative role of tribunals is important for governments, who are repeat function parties, to understand the precise scope of their obligations under BITs. U.N. Doc. A/CN.9/WG.III/WP.145, supra note 53, ๆ 6.

55. Id. 9 Ф $5-7$.

56. U.N. Doc. A/CN.9/WG.III/WP.149, supra note 6, 927.

57. Id. ๆ 26.

58. U.N. Comm'n on Int'l Trade Law, Possible Reform of Investor-State Dispute Settlement (ISDS): Consistency and Related Matters, U.N. Doc. A/CN.9/WG.III/WP.150, ศף 11-13 (2018) [hereinafter U.N. Doc. A/CN.9/WG.III/WP.150]. 
standard in the same investment treaty. ${ }^{59}$ For example, states have reported tribunals reaching different conclusions in an instance of concurrent proceedings with identical facts and provisions. ${ }^{60}$ Second, tribunals have reached divergent conclusions in disputes involving the same state measure and related parties under different treaties. ${ }^{61}$ For example, the two disputes Lauder v. Czech Republic and CME Republic B.V. v. Czech Republic involve the same state measure and alleged harm, with the claimant bringing claims in one proceeding under his own name and in the other proceeding as a shareholder. ${ }^{62}$ Third, tribunals have reached divergent decisions involving unrelated parties but similar facts and treaty provisions. Generally, this scenario occurs when a state action impacts multiple unrelated investors under different treaties. ${ }^{63}$

Currently, no mechanism exists to remedy inconsistencies in arbitral decisions. ${ }^{64}$ While tribunals acknowledge the need to consider the decisions of earlier cases, "no doctrine of binding precedent exists." 65 The lack of consistency in the arbitral decisions impacts both states and investors. It impedes states' abilities to understand whether their regulatory activities conform with the treaty obligations and hinders investors' ability to determine whether certain treatment conforms with the treaty obligations. ${ }^{66}$ Scholars have commented that inconsistent decisions negatively affect the legitimacy of the ISDS system and impede the role of foreign direct investment in facilitating the achievement of the Sustainable Development Goals. ${ }^{67}$

In considering possible reform, the Working Group distinguished between justifiable and unjustifiable divergence in arbitral decisions. Justifiable divergence includes differences in interpretation that stem from the fundamental rules of treaty interpretation, which require the decision maker to take into account more than the

59. For example, the tribunals in SGS v. Islamic Republic of Pakistan and SGS v. Republic of the Philippines reached different conclusions on the question of whether the breach of a local contract constitutes a breach of the investment treaty under the umbrella clause. Both cases involved the same investor, SGS, and similar facts relating to SGS's customs service obligations under local contracts. SGS Société Générale de Surveillance S.A. v. Islamic Republic of Pak., ICSID Case No. ARB/01/13, Decision of the Tribunal on Objections to Jurisdiction (Aug. 6, 2003); SGS Société Générale de Surveillance S.A. v. Republic of the Phil., ICSID Case No. ARB/02/6, Decision of the Tribunal on Objections to Jurisdiction (Jan. 29, 2004) [hereinafter SGS Decision on Jurisdiction]. See also Zuleta, supra note 37, at 414-15.

60. U.N. Doc. A/CN.9/WG.III/WP.150, supra note 58, ๆ 9. Examples include decisions under NAFTA and decisions on the applicability of the most-favored nation clause in investment treaties. $I d$. ๆ 11.

61. Id. ๆ12.

62. Id.; Lauder v. Czech Rep., Ad hoc UNCITRAL Arbitration, Final Award (Sept. 3, 2001); CME Republic B.V. v. Czech Rep., Ad hoc UNCITRAL Arbitration, Final Award (Mar. 14, 2003).

63. Id. $\uparrow 13$.

64. U.N. Comm'n on Int'l Trade Law, Possible Reform of Investor-State Dispute Settlement (ISDS): Comments from the Government of Indonesia, U.N. Doc. A/CN.9/WG.III/WP.156, 13 (2018) [hereinafter U.N. Doc. A/CN.9/WG.III/WP.156].

65. U.N. Doc. A/CN.9/WG.III/WP.149, supra note 6, q 36; see also U.N. Doc. A/CN.9/WG.III/WP.150, supra note 58, 40 ("There is no hierarchy of international tribunals, and even if there were, there is no good reason for allowing the first tribunal in time to resolve issues for all later tribunals.").

66. See U.N. Doc. A/CN.9/964, supra note 2, \30.

67. Id. 
plain language of the treaty. ${ }^{68}$ Unjustifiable divergence includes contradictory interpretations of the same standard within the same treaty. ${ }^{69}$ During the Working Group's deliberations, states reached the conclusion that unjustifiable divergence in arbitral decisions is an issue of material concern and not only one of perception. ${ }^{70}$ The Working Group further noted the importance of addressing inconsistencies at the multilateral level. ${ }^{71}$

The second area of concern relating to arbitral decisions is the incorrect interpretation of treaty provisions. ${ }^{72}$ "Incorrect" interpretations include instances in which the tribunal does not take into account the intent of the treaty parties and instances in which the tribunal reaches decisions based on manifest errors of law or facts. $^{73}$ The current ISDS system does not have systematic controls for the correctness of decisions. $^{74}$ Investment arbitration rules generally do not require review of the decision for correctness before the decision is deemed final. ${ }^{75}$ The International Centre for Settlement of Investment Disputes (ICSID) system allows for annulment of awards only on limited procedural grounds and does not include review for substantive correctness. ${ }^{76}$ Similarly, the New York Convention on the Recognition and Enforcement of Foreign Arbitral Awards only provides limited grounds for review. ${ }^{77}$

68. See U.N. Doc. A/CN.9/WG.III/WP.150, supra note 58, ๆ 6.

69. See U.N. Doc. A/CN.9/964, supra note 2, ๆ 28; U.N. Comm'n on Int'l Trade Law, Rep. of Working Group III on the Work of Its Thirty-Fifth Session, U.N. Doc. A/CN.9/935, I 21 (2018) [hereinafter U.N. Doc. A/CN.9/935].

70. See U.N. Doc. A/CN.9/964, supra note 2, 9 - 28, 30

71. Id. $₫ 38$.

72. Id. $\uparrow 34$; see also U.N. Doc. A/CN.9/WG.III/WP.150, supra note 58, 98.

73. U.N. Doc. A/CN.9/964, supra note 2 , 157.

74. See U.N. Doc. A/CN.9/WG.III/WP.149, supra note 6, ब10; U.N. Doc. A/CN.9/WG.III/WP.150, supra note 58, $₫ 21$.

75. See U.N. Doc. A/CN.9/WG.III/WP.161, supra note 48, ๆ 21; U.N. Doc. A/CN.9/WG.III/WP.149, supra note 6, 10.

76. See U.N. Doc. A/CN.9/WG.III/WP.145, supra note 53, ๆ 29. Article 52(1) of the ICSID Convention allows limited grounds for annulment. See Convention on the Settlement of Investment Disputes between States and Nationals of Other States, 17 U.S.T. 1270, T.I.A.S. No. 6090, 575 U.N.T.S. 159, ๆศ 199-203 (1965) [hereinafter ICSID Convention] ("Either party may request annulment of the award by an application in writing addressed to the Secretary-General on one or more of the following grounds: (a) that the Tribunal was not properly constituted; (b) that the Tribunal has manifestly exceeded its powers; (c) that there was corruption on the part of a member of the Tribunal; (d) that there has been a serious departure from a fundamental rule of procedure; or (e) that the award has failed to state the reasons on which it is based."). See also CMS Gas Transmission Co. v. Republic of Arg., ICSID Case No. ARB/01/8, Decision on Annulment, $\uparrow 158$ (2007) [hereinafter CMS Gas Decision on Annulment] ("[T]he Committee is conscious that it exercises its jurisdiction under a narrow and limited mandate conferred by Article 52 of the ICSID Convention. The scope of this mandate allows annulment as an option only when certain specific conditions exist.").

77. Convention on the Recognition and Enforcement of Foreign Arbitral Awards, Oct. 6, 1958, 330 U.N.T.S. 3, at 124 [hereinafter New York Convention]. 


\section{B. Selection of Arbitrators}

Both actual and perceived independence and impartiality of arbitrators are important for ensuring the legitimacy of the ISDS system. ${ }^{78}$ Independence refers to a "lack of business, financial, or personal relationship between an arbitrator and a party to the arbitration." "I9 Impartiality refers to "the absence of bias or predisposition of the arbitrator or decision maker towards a party." 80 These two requirements are linked to other criteria for selecting arbitrators, such as diversity and competence. ${ }^{81}$ The Working Group noted that the independence and impartiality of decision makers are particularly important for investor-state disputes, as the disputes often involve public policy issues and require democratic accountability. ${ }^{82}$

Currently, although the ICSID and UNCITRAL arbitral rules set forth principles of independence and impartiality for arbitrators, ${ }^{83}$ they do not include specific ethical requirements relating to conflicts of interest that may arise from situations in which the arbitrator assumes multiple roles or from repeat appointments. ${ }^{84}$ Conflicts of interest may arise when arbitrators have participated in negotiating international investment agreements and are later appointed to adjudicate disputes arising from these agreements. ${ }^{85}$ The prevalence of repeat appointments also raises concerns about the possible lack of independence. ${ }^{86}$ Arbitral tribunals have reached different conclusions on the issue of whether repeat appointments constitute a basis for challenging the appointment of arbitrators. ${ }^{87}$ States have agreed, however, that the possible perception of bias is by itself cause for concern. ${ }^{88}$

Scholars have asked whether replacing the current ad hoc appointment system with an ex ante appointment system would enhance the independence and impartiality of arbitrators. ${ }^{89}$ The current ad hoc appointment system, in which parties

78. U.N. Doc. A/CN.9/964, supra note 2, ๆ 67; U.N. Comm'n on Int'1 Trade Law, Possible Reform of Investor-State Dispute Settlement (ISDS): Ensuring Independence and Impartiality on the Part of Arbitrators and Decision Makers in ISDS, U.N. Doc. A/CN.9/WG.III/WP.151, ๆ 9 (2018) [hereinafter U.N. Doc. A/CN.9/WG.III/WP.151].

79. U.N. Doc. A/CN.9/WG.III.WP.151, supra note 78, 11.

80. Id.

81. See U.N. Doc. A/CN.9/964, supra note 2, 9 甲 69, 91-98.

82. Id. I 68; U.N. Doc. A/CN.9/WG.III.WP.151, supra note 78, ๆฯ 12 n.3, 31; U.N. Doc. A/CN.9/964, supra note 2 , 67.

83. U.N. Doc. A/CN.9/WG.III.WP.151, supra note 78, $₫ 11$ n.5.

84. Id. ๆๆ 6(i), 19.

85. Id. ๆ 25; see also U.N. Doc. A/CN.9/WG.III/WP.156, supra note 64, ๆๆ 13-14; U.N. Doc. A/CN.9/964, supra note 2, 972.

86. See id. ๆๆ 23, 26 (identifying repeat appointments as a possible reason for the low diversity in ethnicity and gender in arbitrator appointments).

87. See U.N. Doc. A/CN.9/WG.III/WP.151, supra note 78, 923.

88. U.N. Doc. A/CN.9/964, supra note 2, ๆ 68 ("[I]n order to be considered effective, the ISDS framework should not only ensure actual impartiality and independence of decision makers, but also the appearance thereof.").

89. See U.N. Doc. A/CN.9/WG.III/WP.145, supra note 53, $\uparrow 27$. The ad hoc appointment process in the current ISDS system differs from the appointment process of many other international bodies. For example, the International Court of Justice judges are appointed by the General Assembly and the Security Council, and the European Court of Human Rights judges are elected by the Council of Europe Parliamentary Assembly. See U.N. Comm'n on Int'l Trade Law, Possible Reform of Investor-State 
appoint arbitrators after a dispute has arisen, creates a short term incentive for parties to appoint individuals who would best serve their interests for that particular case. ${ }^{90}$ Parties tend to appoint arbitrators who are known to have a predisposition toward one of the sides to the dispute. ${ }^{91}$ States act in the capacity of a disputing party, rather than in their capacity as sovereigns with long-term interests in providing adjudicative bodies that interpret the substantive provisions of the treaty neutrally. ${ }^{92}$ An ex ante appointment system may create an incentive for states to appoint adjudicators who interpret the treaties without taking into consideration whether the appointing state is the respondent in the dispute or the home state of the investor. ${ }^{93}$

In addition to discussions about standards of independence and impartiality, commentators have noted that arbitrators should have expertise in both public and private international law, as well as familiarity with domestic law. ${ }^{94}$ Currently, the ICSID Convention only requires competence in a limited number of fields, listing expressly "the fields of law, commerce, industry, [and] finance." 95 The small number of individuals with expertise in hearing investor-state disputes raises the concern that the number of individuals with both expertise in hearing investor-state disputes and familiarity with the specialized areas of the law, such as tax or intellectual property, is even smaller. ${ }^{96}$ A 2017 study found that a small group of twenty-five to thirty individuals served as arbitrators in a majority of investor-state disputes. ${ }^{97}$ The repeated appointment of a small group of arbitrators is a factor that may have contributed to the low number of individuals who have expertise in hearing investor-state disputes.

\section{Cost of Proceedings}

A number of factors contribute to the high cost of ISDS proceedings. The three main factors are the size of the arbitral awards, the lack of predictability in the interpretation of key provisions, and the long duration of the proceedings. ${ }^{98}$ The average amount of the awards that tribunals have rendered since 2013 is $\$ 171$

Dispute Settlement (ISDS): Arbitrators and Decision Makers, U.N. Doc. A/CN.9/WG.III/WP.152, ๆ 16 (2018) [hereinafter U.N. Doc. A/CN.9/WG.III/WP.152].

90. See U.N. Doc. A/CN.9/WG.III/WP.145, supra note 53, ๆ 31; U.N. Doc. A/CN.9/964, supra note $2, \boldsymbol{q} 95$.

91. See U.N. Doc. A/CN.9/WG.III/WP.145, supra note 53, ๆ 31; U.N. Doc. A/CN.9/964, supra note 2 , 771.

92. U.N. Doc. A/CN.9/WG.III/WP.145, supra note 53, ๆ 31.

93. $I d$.

94. See U.N.Doc. A/CN.9/WG.III/WP.152, supra note 89, ๆ 31.

95. $I d . \uparrow 32$.

96. States have expressed the view that arbitrators should have expertise in public international law, as well as subject-matter expertise. See U.N. Comm'n on Int'1 Trade Law, Summary of the Intersessional Regional Meeting on Investor-State Dispute Settlement Reform Submitted by the Government of the Dominican Republic, U.N. Doc. A/CN.9/WG.III/WP.160, ๆ 29 (2019) [hereinafter U.N. Doc. A/CN.9/WG.III/WP.160].

97. U.N. Doc. A/CN.9/WG.III.WP.151, supra note 78, 77.

98. See U.N. Doc. A/CN.9/964, supra note 2, ๆ 114; see also U.N. Comm'n on Int'1 Trade Law, Possible Reform of Investor-State Dispute Settlement (ISDS): Cost and Duration, U.N. Doc. A/CN.9/WG.III/WP.153, at 13 (2018) [hereinafter U.N. Doc. A/CN.9/WG.III/WP.153]. 
million. ${ }^{99}$ The lack of predictability and binding precedent causes parties to submit all available arguments to the tribunal, regardless of whether tribunals in earlier disputes have already rejected the arguments. ${ }^{100}$ Further, the limited grounds for appeal prompt parties to invest a substantial amount of resources in raising all possible issues of fact and law before the tribunal. ${ }^{101}$ The small number of arbitrators with expertise in hearing investor-state disputes may also contribute to the costs by causing delays in the appointment process. ${ }^{102}$

A major concern with the high cost of arbitral proceedings is the possibility of regulatory chill. ${ }^{103}$ The Working Group noted that the threat of an investor-state dispute can discourage host states from implementing measures to protect economic, social, and environmental rights. ${ }^{104}$ States expressed the view that claimants often initiate cases with exaggerated claims for monetary compensation, resulting in a large gap between the claimant's and the respondent's valuations. ${ }^{105}$ States are sometimes unable to recover the cost of the proceedings even when they prevail, as tribunals seldom order security for costs. ${ }^{106}$ Developing states are particularly vulnerable to the burden of high costs because they generally do not have government counsel specialized in investor-state disputes and consequently have to rely on external counsel, which may not always be available. ${ }^{107}$ Further, the cost of ISDS proceedings may divert states' funding from fulfilling development needs. ${ }^{108}$

\section{POTENTIAL REFORM OF THE ISDS SYSTEM}

International bodies have on several occasions contemplated establishing a multilateral investment court as a reform solution to address the concerns with the

\footnotetext{
99. U.N. Doc. A/CN.9/WG.III/WP.153, supra note 98, 15.

100. Id. ๆ 85; U.N. Doc. A/CN.9/WG.III/WP.145, supra note 53, ๆ 33.

101. U.N. Doc. A/CN.9/WG.III/WP.153, supra note 98, 85.

102. Id. 89; U.N. Comm'n on Int'l Trade Law, Possible Reform of Investor-State Dispute Settlement (ISDS): Comments by the Government of Thailand, U.N. Doc. A/CN.9/WG.III/WP.147, $₫ 11$ [hereinafter U.N. Doc. A/CN.9/WG.III/WP.147]. The three most time-consuming stages of ISDS proceedings are the appointment of the tribunal, the disclosure and discovery of documents, and the issuance of the award. U.N. Doc. A/CN.9/WG.III/WP.153, supra note 98, $₫ 25$.

103. U.N. Doc. A/CN.9/970, supra note 2, 9ศ 36-37. The Working Group noted that some states were in the process of reforming their investment agreements to preserve the right to regulate. Id. 936. In 2014, Indonesia undertook a review of all international investment agreements to which it was a signatory. Indonesia evaluated the impact of the international investment agreements on its right to regulate and to pursue legitimate public policy objectives. U.N. Doc. A/CN.9/WG.III/WP.156, supra note $64,97$.

104. U.N. Doc. A/CN.9/970, supra note 2, ๆ 36; U.N. Doc. A/CN.9/WG.III/WP.156, supra note 64, I 10; see also U.N. Doc. A/CN.9/WG.III/WP.161, supra note 48, 14 (noting the effect of the rising costs of ISDS proceedings on states' ability to pursue sustainable development).

105. U.N. Doc. A/CN.9/WG.III/WP.156, supra note 64, 98.

106. U.N. Doc. A/CN.9/964, supra note 2, 129.

107. Id. ๆ 111; U.N. Doc. A/CN.9/WG.III/WP.153, supra note 98, ๆ 9; U.N. Doc. A/CN.9/WG.III/WP.147, supra note 102, $₫ 15$.

108. U.N. Doc. A/CN.9/WG.III/WP.153, supra note 98, ๆ 8.
} 
current ISDS system. ${ }^{109}$ For example, in a 2004 discussion paper, the ICSID Secretariat set forth a multilateral appeals mechanism aimed to foster coherency and consistency in the case law arising from investment treaties. ${ }^{110}$ The proposal envisioned a standing appeals panel consisting of fifteen adjudicators, with a panel of three adjudicators appointed from the standing panel to review each dispute for clear error of law or serious error of fact. ${ }^{111}$ The United Nations Conference on Trade and Development (UNCTAD) commented that "[a] standing investment court would be an institutional public good" but that it would, at the same time, be the most difficult reform solution to implement because it requires a complete overhaul of the existing ISDS system. ${ }^{12}$

Some states have also expressed an intent to establish an appeals mechanism for reviewing tribunal awards. The 2013 Canada-Korea Free Trade Agreement states that "the Parties shall consider whether to establish a bilateral appellate body or similar mechanism to review awards rendered pursuant to Article 8.42." 113 Several free trade agreements between the United States and other states provide for negotiations to establish an appeals mechanism. ${ }^{114}$ The 2012 U.S. Model BIT states, in Article 28(10), "[i]n the event that an appellate mechanism for reviewing awards rendered by investor-State dispute settlement tribunals is developed in the future under other institutional arrangements, the Parties shall consider whether awards rendered under Article 34 should be subject to that appellate mechanism." 115

This Part analyzes the multilateral investment court that the European Commission proposed to UNCITRAL Working Group III in January 2019, in response to the Working Group's invitation for member states and international bodies to submit reform solutions. First, this Part sets forth the government-led process of the Working Group's work in completing its mandate. Next, this Part details the structure of the proposed multilateral investment court in the context of the three categories of concerns that the Working Group identified.

\section{A. UNCITRAL'S WORK IN DEVELOPING REFORM SOLUTIONS}

UNCITRAL Working Group III entered into the final phase of its work on the potential reform of the present ISDS system in October 2019. ${ }^{116}$ This phase is a

109. Kaufmann-Kohler \& Potestà, supra note 9, at 20; see also World Investment Report 2015, supra note 6 , at 150-52 (discussing the possibility of establishing an appeals mechanism and a standing court for hearing investor-state disputes).

110. Kaufmann-Kohler \& Potestà, supra note 9, at 20-21. ICSID later stayed the proposal due to insufficient support from member states. $I d$.

111. Id. at 21 .

112. Marc Bungenberg \& August Reinisch, From Bilateral arbitral Tribunals and INVESTMENT COURTS TO A MULTILATERAL INVESTMENT COURT 1 (2018).

113. Free Trade Agreement, Can.-S. Kor., Annex 8-E, Sept. 24, 2014. See also Kaufmann-Kohler \& Potestà, supra note 9 , at 22-23.

114. Bottini, supra note 3, at 456.

115. U.S. Trade Representative, U.S. Model Bilateral InVestment Treaty art. 28(10) (2012) [hereinafter 2012 U.S. Model BIT]. See also Kaufmann-Kohler \& Potestà, supra note 9, at 22.

116. U.N. Doc. A/CN.9/1004, supra note 2, \ 27; see also U.N. Doc. A/CN.9/970, supra note 2, ๆๆ 80-85. Fifty-four member States of UNCITRAL attended the thirty-eighth session of Working Group III, 
government-led process of developing solutions to address the identified concerns with the current ISDS system. ${ }^{117}$ Since its establishment, UNCITRAL has carried out most of its work through an intergovernmental process within the United Nations. Typically, UNCITRAL working groups prepare legal texts that the UNCITRAL Commission then finalizes at the Commission's annual session. ${ }^{118}$ The working groups implement a formal negotiation process that aims to create a transparent and inclusive multilateral forum. ${ }^{119}$ In beginning the final phase of its mandate, Working Group III heard proposals from member states on possible work plans. ${ }^{120}$ The Working Group considered concerns such as the priority of addressing the identified issues, the sequence of deliberations, the possibility of multiple tracks, and the coordination of work with other international organizations. ${ }^{121}$

The member states of UNCITRAL proposed a number of reform options for addressing the identified issues. ${ }^{122}$ The proposals include preparing ISDS procedural rules, establishing an advisory center on international investment law, and prioritizing concerns using criteria such as the level of urgency. ${ }^{123}$ Some states also suggested dividing the work into two separate work streams. One work stream would focus on issues relating to a code of conduct for arbitrators, costs, concurrent proceedings, and counterclaims. ${ }^{124}$ The other work stream would focus on issues relating to structural reform, appeals mechanisms, and enforcement. ${ }^{125}$

Among the various proposals, the European Commission's proposal to establish "a multilateral investment court with a built-in appeal mechanism" has been the subject of considerable discussion among scholars and international bodies. ${ }^{126}$ The proposed multilateral court aims to enhance standards of transparency, legitimacy, and fairness in ISDS. ${ }^{127}$ The Working Group noted that this reform option would be a systemic reform option to comprehensively address the identified concerns with the existing ISDS system. ${ }^{128}$ The reform would be implemented through a

in which the Working Group began the final phase of its mandate. U.N. Doc. A/CN.9/1004, supra note 2, ๆ 5 .

117. States reiterated the view that "the effectiveness and legitimacy of this process rest on the active participation of both developing and developed states to present their experiences and visions on the direction and content of any possible reform." U.N. Comm'n on Int'1 Trade Law, Possible Reform of Investor-State Dispute Settlement (ISDS): Submission from the European Union and Its Member States, U.N. Doc. A/CN.9/WG.III/WP.159, 12 [hereinafter U.N. Doc. A/CN.9/WG.III/WP.159].

118. U.N. Comm'n on Int'1 Trade Law, Possible Reform of Investor-State Dispute Settlement: Information on Options for Implementing a Workplan, U.N. Doc. A/CN.9/WG.III/WP.158, of 4 [hereinafter U.N. Doc. A/CN.9/WG.III/WP.158].

119. Id. $\llbracket 5$.

120. The Working Group emphasized that the member states agreed on the need for ISDS reform. U.N. Doc. A/CN.9/970, supra note 2, \73.

121. U.N. Doc. A/CN.9/964, supra note 2, 19.

122. The Working Group asked for member states and international bodies to submit reform proposals to the Working Group before July 15, 2019. U.N. Doc. A/CN.9/970, supra note 2, $\uparrow 83$.

123. Id. ๆฯ 66-67, 69, 79 .

124. Id. $\uparrow 74$.

125. Id.

126. Id. 971 .

127. Id.

128. Id. 
mechanism similar to that of the recently ratified UNCITRAL Transparency Rules and would be binding only to the extent that states opt in. ${ }^{129}$

\section{B. The European Commission's Proposal for a Multilateral INVESTMENT COURT}

The European Commission submitted a proposal to UNCITRAL Working Group III on January 18,2019 , to establish a multilateral investment court for the settlement of investor-state disputes. ${ }^{130}$ The submission follows a paper that the European Commission submitted on November 20, 2017, at the thirty-fifth session of Working Group III, that identified concerns with the existing ISDS system. ${ }^{131}$ The European Commission first introduced the concept of a multilateral investment court at the Committee on International Trade on March 18, 2015. ${ }^{132}$ The European Commission then presented the structures of a bilateral investment court system in May, 2015, and proposed the bilateral court system in its negotiations with the United States for the Transatlantic Trade and Investment Partnership (TTIP) during the fall of the same year. ${ }^{133}$ The European Commission included the bilateral court system in both the Comprehensive Economic and Trade Agreement (CETA) with Canada and the EUVietnam Investment Protection Agreement. ${ }^{134}$ Both CETA and the EU-Vietnam Investment Protection Agreement include a provision that expresses the intent to establish a multilateral court system. ${ }^{135}$ In March 2018, the Council of the European Union mandated the European Commission to negotiate a multilateral court system for resolving investor-state disputes. ${ }^{136}$

129. Id. The opt-in mechanism would allow states to accede to the instrument establishing the standing mechanism. For future investment agreements, parties could include in the agreement that they confer jurisdiction on the standing mechanism. U.N. Doc. A/CN.9/WG.III/WP.159/Add.1, supra note1 17, 9ศ 35-36.

130. U.N. Doc. A/CN.9/WG.III/WP.159/Add.1, supra note 117, \ 1; see also id. 12 (noting that the proposal is the result of "considerable reflection of the EU and its Member States on possible multilateral reform over the last years").

131. U.N. Doc. A/CN.9/WG.III/WP.145, supra note 53, ๆ 1. The paper responds to a Note by the UNCITRAL Secretariat, dated 18 September 2017, U.N. Doc. A/CN.9/WG.III/WP.142. The paper considers the framework of the current ISDS system and compares it to other systems with similar attributes. Id. $₫ 2$.

132. BUNGENBERG \& REINISCH, supra note 112 , at 2.

133. Id.

134. Id.; Kaufmann-Kohler \& Potestà, supra note 9, at 23. The bilateral investment court system includes a tribunal of first instance, serving for a fixed term of four or five years, and an appellate tribunal. The tribunal of first instance would consist of one third nationals of a European Union member state, one third nationals of the other party to the Agreement, and one third nationals of third countries. The appellate level would hear cases on grounds of ICSID Convention Article 52. Kaufmann-Kohler \& Potestà, supra note 9 , at 24 .

135. Comprehensive Economic \& Trade Agreement, Can.-E.U., art. 8.29, Oct. 30, 2016 [hereinafter CETA] ("The Parties shall pursue with other trading partners the establishment of a multilateral investment tribunal and appellate mechanism for the resolution of investment disputes."); EU-Vietnam Investment Protection Agreement, E.U.-Viet., chp. 3, art. 3.41, June 30, 2019 [hereinafter EU-Vietnam Investment Protection Agreement] ("[The Parties] shall enter into negotiations for an international agreement providing for a multilateral investment tribunal in combination with, or separate from, a multilateral appellate mechanism applicable to disputes under this Agreement.").

136. BUNGENBERG \& REINISCH, supra note 112, at 1. 
The European Commission's submission to UNCITRAL proposes a multilateral investment court with two levels of adjudication. The first level is a tribunal of first instance that would conduct fact finding and apply the relevant law. ${ }^{137}$ It would have its own rules of procedure. ${ }^{138}$ It would also decide on cases remanded back to it from the second level of adjudication, which is the appellate level. The appellate tribunal would hear appeals from the tribunal of first instance. ${ }^{139}$ Grounds of appeal would be error of law or manifest errors in the appreciation of facts. ${ }^{140}$ To prevent the abuse of the appeals mechanism, the proposal suggests including measures such as requiring security for costs. ${ }^{141}$

With regard to the selection of adjudicators, the proposal outlines expertise and procedural requirements. The proposal requires adjudicators to have expertise in public international law. ${ }^{142}$ It suggests implementing comparable qualification requirements to those of other international courts. ${ }^{143}$ For example, adjudicators may be required to have the qualifications for appointment to the highest judicial offices of their respective countries. ${ }^{144}$ The proposal notes the possibility of including additional expertise requirements for certain areas of law. ${ }^{145}$ The standing panel of adjudicators would consist of state-appointed adjudicators who are employed full time and who conform to independence and impartiality standards. ${ }^{146}$ The proposal leaves open the number of adjudicators and the length of term. It notes that long-term non-renewable appointments would facilitate independence from the appointing state and would obviate the need for adjudicators to seek other remuneration. ${ }^{147}$ The adjudicators would have salaries comparable to those of adjudicators of other international courts. ${ }^{148}$ The proposal suggests a random process for selecting the adjudicators for each dispute so that the disputing parties would not know in advance which adjudicators would preside over the dispute. ${ }^{149}$

The proposal contemplates allowing parties to participate in interpreting the treaty language. It leaves open the possibility of permitting treaty parties to adopt binding interpretations for the treaty language. ${ }^{150}$ It notes the possibility of allowing the home state of the investor to participate in the dispute. ${ }^{151}$ It further contemplates permitting states that are party to the instrument establishing the standing court to

137. U.N. Doc. A/CN.9/WG.III/WP.159/Add.1, supra note 117, ๆ 13; see Kaufmann-Kohler \& Potestà, supra note 9 , at $34-41$ (discussing whether a permanent tribunal would qualify as arbitration).

138. U.N. Doc. A/CN.9/WG.III/WP.159/Add.1, supra note 117, \ 13.

139. Id. $₫ 14$.

140. U.N. Doc. A/CN.9/WG.III/WP.159/Add.1, supra note 117, 14.

141. Id. $\uparrow 15$.

142. Id. 949 .

143. Id. $\uparrow 20$.

144. Id.

145. Id.

146. Id. 918.

147. Id. $\uparrow 19$.

148. Id. 917

149. Id. 924.

150. Id. 926 (referring to Article IX.2 of the WTO Agreement).

151. Id. $\mid 25$. 
participate in interpreting the language of treaties to which they are not contracting parties. $^{152}$

\section{ISDS AS A FORUM FOR ENFORCING STATES' INTELLECTUAL PROPERTY OBLIGATIONS}

On March 16, 2017, the tribunal in Eli Lilly v. Canada issued the first final award in an investor-state dispute involving patent law, marking ISDS as a new forum for private investors to seek protection for their intellectual property rights in the host state. ${ }^{153}$ In Eli Lilly v. Canada, Eli Lilly filed claims against Canada under NAFTA Article 1110 for expropriation and under NAFTA Article 1105 for the alleged breach of the fair and equitable (FET) standard. ${ }^{154}$ The dispute between Eli Lilly and Canada involved, in the context of revoking a patent, the issue of how much flexibility domestic courts have in modifying domestic intellectual property law. ${ }^{155}$ Although the tribunal ultimately ruled in favor of Canada, the tribunal did not rule on the merits of the expropriation and FET claims, ${ }^{156}$ leaving open the possibility that future tribunals may rule on these issues in a manner that limits the flexibilities that states have in implementing treaty obligations. ${ }^{157}$ This Part examines the FET standard as one possible avenue by which investors may seek to enforce a host state's intellectual property obligations in investor-state arbitration.

Tribunals have considered various elements when evaluating a host state's actions under the FET standard, such as reasonableness, consistency, and due process. ${ }^{158}$ While the exact elements of the FET standard remain context-specific, tribunals have generally considered the investor's legitimate expectations in the host state's investment environment to be a central element of the standard. ${ }^{159}$ In International Thunderbird v. Mexico, the tribunal stated that the investor's legitimate expectations arise from "a situation where a Contracting Party's conduct creates reasonable and justifiable expectations on the part of an investor (or investment) to act in reliance

152. Id. $₫ 27$.

153. Eli Lilly Final Award, supra note 31; Lentner, supra note 31.

154. Eli Lilly \& Co. v. Canada, ICSID Case No. UNCT/14/2, Notice of Arbitration, qศ 72-84 (Sept. 12, 2013) [hereinafter Eli Lilly Notice of Arbitration].

155. Liddell \& Waibel, supra note 28 , at 3.

156. The Tribunal found that Eli Lilly had failed to establish the factual predicates for these two claims. The two factual questions that the tribunal considered were whether Canada's utility requirement dramatically changed over time and whether Canada's utility requirement as applied to Eli Lilly's patents was arbitrary or discriminatory. Cynthia M. Ho, A Collision Course Between TRIPS Flexibilities and Investor-State Proceedings, 6 UC IRVINE L. REV. 395, 444 (2016) [hereinafter Ho, A Collision Course].

157. Id.

158. Henning Grosse Ruse-Khan, Litigating Intellectual Property Rights in Investor-State Arbitration: From Plain Packaging To Patent Revocation, LEGAL STUD. RSCH. PAPER SERIES, Paper No. 52/2014, University of Cambridge, at 20 (2014) [hereinafter Grosse Ruse-Khan, Litigating Intellectual Property Rights]. In Waste Management, the tribunal stated that the FET standard is infringed "if the conduct is arbitrary, grossly unfair, unjust or idiosyncratic, is discriminatory and exposes the claimant to sectional or racial prejudice, or involves a lack of due process leading to an outcome which offends judicial propriety." Waste Mgmt., Inc. v. United Mexican States, ICSID Case No. ARB(AF)/00/3, Award, ๆ 98 (Apr. 30, 2004) [hereinafter Waste Management Award].

159. Grosse Ruse-Khan, Litigating Intellectual Property Rights, supra note 158, at 20. 
on said conduct, such that a failure by the NAFTA Party to honor those expectations could cause the investor to suffer damages." 160

The tribunal's ruling in Eli Lilly leaves open the possibility that future tribunals may review a host state's intellectual property laws when evaluating the investor's legitimate expectations under the FET standard. Eli Lilly alleged the breach of the FET standard under NAFTA Article 1105, arguing that Canada's judicial invalidation of the patents was inconsistent with Eli Lilly's legitimate expectation of a stable business environment. ${ }^{161}$ Eli Lilly argued that it "could not have anticipated that the requirement for utility at the time of its investment would be so drastically altered by the creation of the promise doctrine."162 Eli Lilly further alleged that the promise doctrine violated "Canada's obligation to refrain from conduct that is arbitrary, unfair, unjust, and discriminatory."163

The scope and the source of the investor's legitimate expectations under the FET standard is a debated issue. Tribunals have generally followed two approaches in defining the legitimate expectations of investors: the broad approach of requiring a state to ensure a stable legal environment ${ }^{164}$ and the more narrow approach of focusing on specific state representations to the investor. ${ }^{165}$ Investors have commonly claimed legitimate expectations in the host state's investment environment on the following grounds: (1) the investor's intellectual property rights in the host state; (2) the host state's intellectual property obligations under international agreements; and (3) the investment treaty's "safeguard provision" that exempts certain state actions from a finding of expropriation.

160. Id. at 21 .

161. Eli Lilly Notice of Arbitration, supra note 154, ๆ 82. Canadian patent law uses the promise doctrine to determine whether an invention fulfills the utility requirement, which is one of the requirements for granting a patent. Eli Lilly's claims challenged Canada's judicial invalidation of two of Eli Lilly's patents for failure to meet the utility requirement. The patents sought additional protection for the basic chemical compound underlying each drug after an earlier patent for the drug had expired. The Canadian judiciary found that the patents failed to satisfy the promise doctrine because the patents did not present data to establish that the drugs would fulfill the promises of treating Attention Deficit Hyperactivity Disorder and psychosis with long-term use. Ho, A Collision Course, supra note 156, at 441.

162. Eli Lilly Notice of Arbitration, supra note 154, 982.

163. Id. ๆ 81.

164. Técnicas Medioambientales Tecmed S.A. v. United Mexican States, ICSID Case No. ARB (AF)/00/2, Award, ๆ 154 (May 29, 2003) [hereinafter Tecmed Award] ("The Host State must act in a consistent manner, free from ambiguity and totally transparently in its relations with the foreign investor, so that it may know beforehand any and all rules and regulations that will govern its investments, as well as the goals of the relevant policies and administrative practices or directives, to be able to plan its investment and comply with such regulations.").

165. Ho, supra note 17, at 275. In CMS v. Argentina and Enron v. Argentina, the tribunal found that Argentina violated the FET standard by dismantling its tariff guarantees, on which foreign companies relied to make investments in Argentina. Id. at 277. 


\section{A. The Investor's Intellectual Property Rights in the Host State}

Investors have alleged violations of their legitimate expectations under the FET standard by arguing that the host state frustrated their intellectual property rights. ${ }^{166}$ Tribunals have concluded that in order to show the existence of legitimate expectations, the investor must show that the host state has made a specific commitment to the investor on which the investor can rely. ${ }^{167}$ Tribunals have defined "specific commitment" as a representation from the host state to the investor that has the "precise object[ive] . . . to give a real guarantee of stability to the investor." 168 In Total v. Argentina, the tribunal found that respondent Argentina violated the FET standard by eliminating customs duty exemptions on oil exports after Argentina had specifically promised not to do so. ${ }^{169}$ Argentina had assured the investor of customs duty exemptions for a period of four years in response to the investor's requests. ${ }^{170}$

The decisions from past disputes suggest that intellectual property rights alone cannot confer legitimate expectations on which an investor can base an FET claim. ${ }^{171}$ In a 2005 WTO Panel Report, EC-Geographical Indications, the WTO Panel distinguished between negative and positive rights, concluding that intellectual property rights grant negative rights that prevent others from doing certain acts, rather than positive rights to use certain subject matter. ${ }^{172}$ The Panel concluded that negative rights alone cannot prevent states from enacting measures on the production, sale, or use of patented products. ${ }^{173}$ Scholars have noted that the granting of a patent cannot by itself constitute a specific commitment to the investor because the granting of a patent is conditional upon potential future revocation from a judicial finding of invalidity. ${ }^{174}$

166. For example, in Eli Lilly v. Canada, Eli Lilly argued that the Canadian courts' invalidation of its patents violated the FET standard because the measures "constitute[d] a sudden, arbitrary and discriminatory alteration of the framework governing Lilly's investment that contravene[d] Lilly's most basic and legitimate expectations of a stable business and legal environment." Grosse Ruse-Khan, Litigating Intellectual Property Rights, supra note 158, at 23.

167. In Total v. Argentina, the tribunal found that no legitimate expectation existed for the law to remain unchanged because the state did not explicitly make a legal obligation using, for example, a stabilization clause. Total S.A. v. Argentine Republic, ICSID Case No. ARB/04/01, Decision on Liability, ๆๆ 309-10 (Dec. 27, 2010) [hereinafter Total Decision on Liability]. In Methanex, the tribunal found no violation of the FET standard because California made no representation that its regulatory laws would not change. Methanex Corp. v. United States, 44 I.L.M. 1345, Final Award on Jurisdiction and Merits, Part IV, Chapter D, 9甲 8-9 (Aug. 3, 2005) [hereinafter Methanex Final Award].

168. El Paso Energy Int'l Co. v. Argentine Republic, ICSID Case No. ARB/03/15, Award, ๆ 377 (Oct. 31, 2011) [hereinafter El Paso Award].

169. Liddell \& Waibel, supra note 28, at 22.

170. Id.

171. Ho, supra note 17 , at 279 .

172. Grosse Ruse-Khan, Litigating Intellectual Property Rights, supra note 158, at 25 (citing WORLD TRADE ORG., EUROPEAN COMMUNITIES-PROTECTION OF TRADEMARKS AND GEOGRAPHICAL INDICATIONS FOR AGRICULTURAL PRODUCTS AND FOODSTUFFS, WT/DS174/R (2005)).

173. Id.

174. See Liddell \& Waibel, supra note 28, at 29-30 (drawing a distinction between the question of whether the court changed the patent law in a way that breached the FET standard and the question of whether the court interpreted an existing law in a way that breached the FET); see also European Communities-Protection of Trademarks and Geographical Indications for Agricultural Products and 


\section{B. The Host State's International Intellectual Property OBLigations}

Investors have invoked the host state's intellectual property obligations under international agreements as a source of legitimate expectations in alleging the breach of the FET standard. For example, Eli Lilly argued that "Canada ha[d] a positive obligation to ensure [that] Canadian law complie[d] with Canada's international treaty obligations" and that "Lilly could not reasonably have expected that Canada's patent regime... would develop in a manner that depart[ed] so markedly from Canada's international obligations." 175 Similarly, Philip Morris, in its dispute challenging Australia's trademark law governing tobacco packaging, stated that it had the "legitimate expectation that Australia [would] compl[y] with its international trade treaty obligations." 176

The fact that the host state owes its international treaty obligations to other states, rather than to private parties, suggests that private parties cannot invoke them as a basis for legitimate expectations. Henning Grosse Ruse-Khan commented that a host state's intellectual property obligations under international agreements can only create legitimate expectations for the investor when the obligations are directly applicable under domestic law, sufficiently concrete to be applied by domestic institutions, and give rise to the investor's individual rights. ${ }^{177}$ Under this framework, the language of the TRIPS Agreement and of NAFTA are not sufficiently concrete to give rise to legitimate expectations because the language allows flexibility in the application of the rules. ${ }^{178}$ With regard to NAFTA, the exclusive jurisdiction of the WTO dispute settlement system further suggests that the host state's obligations under WTO agreements cannot serve as a basis for the investor's legitimate expectations under the FET standard. ${ }^{179}$

\footnotetext{
Foodstuffs, WT/DS290/R, Appellate Body Report, 7.246 (Mar. 15, 2005) [hereinafter EC-Trademarks Appellate Body Report] ("[A] fundamental feature of intellectual property protection inherently grants Members freedom to pursue legitimate public policy objectives since many measures to attain the public policy objectives lie outside the scope of intellectual property and do not require an exception under the TRIPS Agreement.").

175. Grosse Ruse-Khan, Litigating Intellectual Property Rights, supra note 158, at 26.

176. $I d$. at 22 .

177. Id. at 27-28.

178. See TRIPS: Agreement on Trade-Related Aspects of Intellectual Property Rights, art. 20, Apr. 15, 1994, Marrakesh Agreement Establishing the World Trade Organization, Annex 1C, 1869 U.N.T.S. 299, 33 I.L.M. 1197 (1994) [hereinafter TRIPS Agreement] (stating that the use of trademarks shall not be "unjustifiable"); see also North America Free Trade Agreement (NAFTA) art. 1709:1, Can.-Mex.U.S., Dec. 17, 1992, 107 Stat. 2006, 32 I.L.M. 289 \& 605 [hereinafter NAFTA] (entered into force Jan. 1, 1994) (stating that patents must be "capable of industrial application").

179. Grosse Ruse-Khan, Litigating Intellectual Property Rights, supra note 158, at 27 ("When Members seek the redress of a violation of obligations or other nullification or impairment of benefits under the covered agreements or an impediment to the attainment of any objective of the covered agreements, they shall have recourse to, and abide by, the rules and procedures of this Understanding." (citation omitted)).
} 


\section{Safeguard Provisions}

Treaty provisions that safeguard certain state actions from constituting expropriation may serve as a basis for the investor to invoke the host state's international intellectual property obligations as the reason for the investor's legitimate expectations in the host state's investment environment. An example of such a "safeguard provision" is Article 6(5) of the 2012 United States Model Bilateral Investment Treaty (2012 U.S. Model BIT), which states that "the revocation, limitation, or creation of intellectual property rights" do not amount to expropriation if such state actions are consistent with the state's obligations under the TRIPS Agreement. ${ }^{180}$ Similarly, NAFTA Article 1110(7) states that "the issuance of compulsory licenses" and "the revocation, limitation or creation of intellectual property rights" are exempt from expropriation charges if such measures are consistent with NAFTA's intellectual property chapter. ${ }^{181}$ Safeguard provisions allow tribunals to evaluate whether the host state has complied with its obligations under the relevant international agreements governing intellectual property. In this way, safeguard provisions present an avenue for investors to challenge the host state's measures for compliance with international intellectual property rules.

Eli Lilly asserted its expropriation claim against Canada under NAFTA Chapter 11 and argued that the safeguard provision, NAFTA Article 1110(7), was inapplicable because Canada breached its obligations under NAFTA Chapter 17 relating to intellectual property protection. ${ }^{182}$ Article $1110(7)$ exempts certain state measures from a finding of expropriation if such measures are consistent with Chapter 17. ${ }^{183}$ The two relevant provisions are Articles 1709(1) and 1709(8). Article 1709 (1) requires states to grant patents on inventions that satisfy the patentability requirements, and Article 1709(8) allows states to revoke a patent only when "grounds exist that would have justified a refusal to grant the patent."184 Eli Lilly argued that Canada breached its Chapter 17 obligations because the promise doctrine did not exist at the time that the Canadian patent office examined the two patent applications. ${ }^{185}$ Lilly also argued that the promise doctrine imposed a "significantly higher burden on the patentee than the standard of utility mandated by NAFTA" and that Canada could not "re-interpret a core patentability requirement . . . in a way that contradict[ed] the standard accepted by the NAFTA parties at the time [that] the treaty was negotiated." 186

The tribunal in Eli Lilly did not rule on the safeguard provision, thus leaving open the possibility that future tribunals may evaluate whether a host state's measures

180. 2012 U.S. Model BIT, supra note 115, art. 6(5).

181. NAFTA, supra note 181, art. 1110(7).

182. See Eli Lilly Notice of Arbitration, supra note 154, 9 甲 5, 6, 78 ("Canada’s failure to fulfill its side of this bargain is unfair and contrary to recognized principles for the protection of intellectual property."); NAFTA, supra note 181, ch. 11 (grants private investors the right to bring claims for a host state's breach of its Chapter 11 obligations.); Ho, supra note 17, at 259-60.

183. See Ho, supra note 17, at 259-60.

184. Eli Lilly Notice of Arbitration, supra note 154, ๆๆ 68-69.

185. Id. ๆ 69.

186. Id. $₫ 68$. 
comply with separate international agreements that govern intellectual property. ${ }^{187}$ By allowing investors to challenge the host state's measures for conformance with the provisions of international agreements, safeguard provisions shift the interpretation of the intellectual property rules from the designated dispute settlement forum of these agreements to ISDS. Shifting the forum to ISDS raises the question of whether arbitral tribunals must take into account the broader purpose of the relevant international agreement when evaluating the host state's conformance to the agreement's intellectual property provision. ${ }^{188}$ Safeguard provisions additionally shift the burden of proof from the claimant to the host state. ${ }^{189}$ Under the WTO dispute settlement system, the party for the affirmative of any claim or defense bears the initial burden of proof. ${ }^{190}$ In contrast, safeguard provisions place the burden on the respondent host state to show compliance. ${ }^{191}$

\section{ISSUES SPECIFIC TO INVESTOR-STATE DISPUTES INVOLVING INTELLECTUAL PROPERTY LAW}

Investment law and intellectual property law are both specialized areas that have traditionally focused on different subjects. ${ }^{192}$ While investment law focuses on tangible assets, intellectual property law focuses on intangible expressions of the mind. ${ }^{193}$ Intellectual property law is generally considered to be an area that is separate from investment law. ${ }^{194}$ The property that intellectual property rights protect is the information or knowledge that results from intellectual activity. ${ }^{195}$ WIPO defines intellectual property as "creations of the mind: inventions, literary and artistic works, and symbols, names, images, and designs used in commerce."196

187. The tribunal found that the state measure invalidating the two patents did not amount to expropriation, as no "fundamental or dramatic change" had occurred in Canada's patent law. The tribunal concluded that it thus did not need to address whether Article 1110(7) was applicable. Eli Lilly Final

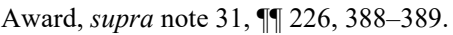

188. CETA includes language that clarifies the parties' intent to only allow investors to enforce the state's obligations under the investment chapter and not the intellectual property chapter. See CETA, supra note 135, Article X.11 (6) ("For greater certainty, the revocation, limitation or creation of intellectual property rights to the extent that these measures are consistent with TRIPS and Chapter X (Intellectual Property) of this Agreement, do not constitute expropriation. Moreover, a determination that these actions are inconsistent with the TRIPS Agreement or Chapter X (Intellectual Property) of this Agreement does not establish that there has been an expropriation."). Similarly, the Doha Declaration states that "each provision of the TRIPS Agreement shall be read in the light of the object and purpose of the Agreement as expressed, in particular, in its objectives and principles." World Trade Organization, Ministerial Declaration of 14 November 2001, ๆ 5, WTO Doc. WT/MIN(01)/DEC/1, 41 ILM 746 (2002) [hereinafter Doha Declaration].

189. See Grosse Ruse-Khan, Litigating Intellectual Property Rights, supra note 158, at 35.

190. Id. at $35 \mathrm{n} .165$.

191. Id. at 35 .

192. See Okediji, supra note 37 , at 1125 (noting that intellectual property differs considerably from most other types of investment).

193. See Mirela V. Hristova, Are Intellectual Property Rights Human Rights?, 93 J. PAT. \& TRADEMARK OFF. SOC'Y 339, 345 (2011).

194. See Ho, A Collision Course, supra note 156, at 419.

195. Id.

196. WIPO, What is Intellectual Property? (2020), https://perma.cc/5RF7-5JB8. 
This Part analyzes the extent to which the proposed multilateral investment court addresses issues that are specific to investor-state disputes that involve intellectual property law. First, this Part considers the issues that arise from the arbitral tribunal's role in disputes that involve laws governing intellectual property at the international and domestic levels. This Part shows that these issues are separate from the ones that have been at the center of discussions about the potential reform of the ISDS system. In light of these issues, this Part proposes including expertise in the international agreements governing intellectual property as a consideration for selecting adjudicators to the permanent panel in the proposed multilateral investment court. Next, this Part analyzes the possible constraints that investor-state disputes may impose on the host state's regulatory space for domestic policies relating to intellectual property. This Part proposes giving deference to the host state's courts in disputes that involve issues of domestic intellectual property law through either a choice of law provision or a standard of review provision in the statute governing the proposed court.

\section{A. Application of the Intellectual Property Rules From INTERNATIONAL AGREEMENTS}

Investor-state disputes that involve the intellectual property provisions of a separate international agreement concern the sanctity of that separate agreement. Scholars have noted that, even if a state chooses to limit its domestic sovereignty when it signs an investment treaty, the goal of the investment treaty is generally not to constrain other international agreements. ${ }^{197}$ The rulings of arbitral tribunals in investor-state disputes that involve intellectual property may undermine the aims of other international agreements. For example, investors may challenge in investorstate arbitration a host state's decision to take advantage of the flexibilities that the TRIPS Agreement affords to developing countries in satisfying the TRIPS Agreement obligations. ${ }^{198}$ Article 8 of the TRIPS Agreement allows member states to "adopt measures necessary to protect public health and nutrition, and to promote the public interest in sectors of vital importance to their socio-economic and technological development, provided that such measures are consistent with the provisions of the Agreement." 199 The Doha Declaration further clarifies member

197. See Ho, A Collision Course, supra note 156, at 425; see also Okediji, supra note 37, at 1129 ("[T]he repetition of intellectual property standards in multiple bilateral, investment, and multilateral treaties were not meant to change the substantive meaning of these obligations under domestic law, but rather to entrench accepted criteria in the fabric of international economic relations. Accordingly, an interpretation of NAFTA's provisions must take place in the broader context of this network of treaties.").

198. See Okediji, supra note 37, at 1128 (In India-Patent Protection for Pharmaceutical and Agricultural Chemical Products, the WTO Appellate Body stated that TRIPS obligations are only limited to minimum standards.). Member states of the WTO can implement exceptions to the exclusive rights of patent owners as long as the exceptions "do not unreasonably conflict with a normal exploitation of the patent and do not unreasonably prejudice the legitimate interests of the patent owner." Marla L. Mellino, The TRIPS Agreement: Helping or Hurting Least Developed Countries' Access To Essential Pharmaceuticals?, 20 FordHAM INTELL. PROP. MEDIA \& ENT. L.J. 1349, 1356 (2010).

199. Mellino, supra note 198, at 1355. 
states' right to issue compulsory licenses. ${ }^{200}$ Despite the flexibilities that the TRIPS Agreement and the Doha Declaration afford to states, investors may file claims in investor-state arbitration to challenge certain aspects of the host state's implementation of these flexibilities. ${ }^{201}$ Investor-state disputes that challenge TRIPS flexibilities may cause developing states to be hesitant to take advantage of the flexibilities. ${ }^{202}$

Arbitral tribunals' interpretations of the intellectual property provisions of international agreements may differ from those of the designated dispute settlement panel for the agreements. ${ }^{203}$ Scholars have noted that arbitral tribunals may find a host state to be liable under the investment chapter of a bilateral investment treaty even when the state is complying with the TRIPS Agreement. ${ }^{204}$ When ruling on disputes arising from the TRIPS Agreement, WTO Panels take into consideration public international law regimes and relevant local conditions to determine the scope of the host state's obligations. ${ }^{205}$ Arbitral tribunals may be unfamiliar with these interpretation approaches. Additionally, arbitral tribunals may encounter issues of interpretation without guidance from the existing case law of the designated dispute settlement forum. ${ }^{206}$

Allowing private investors to enforce the host state's obligations under the intellectual property provisions of international agreements may undermine the negotiations of member states to the agreements. During the negotiations process of free trade agreements, states agree to undertake the obligations vis-à-vis other member states rather than private parties. ${ }^{207}$ The negotiations process suggests that states generally do not contemplate allowing private parties to enforce the state's obligations under the agreements. ${ }^{208}$ Ernst-Ulrich Petersmann has commented that the objectives of the investment chapter and of the intellectual property chapter in

200. The Doha Declaration expressly states that "each member has the right to grant compulsory licenses and the freedom to determine the grounds upon which such licenses are granted." Id. at 1359. The Doha Declaration clarifies that the TRIPS Agreement "can and should be interpreted and implemented in a manner supportive of [the] WTO Member's right to protect public health." Ernst-Ulrich Petersmann, How to Reconcile Health Law and Economic Law with Human Rights? Administration of Justice in Tobacco Control Disputes, 10 ASIAN J. WTO \& INT'L HEALTH L. \& POL'y 27, 58 (2015).

201. For example, Bayer challenged the remuneration rate of India's compulsory license for the cancer drug Nexavar, seeking a royalty rate of fifteen percent of net sales even though India's compulsory license rate was within the World Health Organization's and the United Nations Development Programme's guidelines. See Ho, supra note 17, at 287.

202. Id. at 217 .

203. Id. at 247-49. For example, TRIPS Agreement Article 64 states that disputes relating to states' obligations under the Agreement are subject to the WTO's dispute settlement procedures. TRIPS Agreement, supra note 178, Part V, Article 64(1) ("The provisions of Articles XXII and XXIII of GATT 1994 as elaborated and applied by the Dispute Settlement Understanding shall apply to consultations and the settlement of disputes under this Agreement except as otherwise specifically provided herein.”). The Dispute Settlement Understanding is the main WTO agreement on settling disputes and sets forth the rules for WTO Panels to hear disputes. See Word Trade Organization, Dispute Settlement, https://perma.cc/59P4-YWRN.

204. See Ho, supra note 17, at 247-48.

205. See Okediji, supra note 37, at 1131.

206. Grosse Ruse-Khan, Litigating Intellectual Property Rights, supra note 158, at 37.

207. Liddell \& Waibel, supra note 28, at 26 n.94.

208. Ho, supra note 17, at 250 . 
international investment agreements are fundamentally different. ${ }^{209}$ In noting this distinction, Petersmann expressed the view that arbitral tribunals should take into account the principles of an international system of justice when ruling on specific provisions of investment treaties. ${ }^{210}$

While the European Commission's proposal contemplates a permanent panel of adjudicators with expertise in public international law, the possibility remains that the adjudicators may be unfamiliar with the interpretation of the international agreements that govern intellectual property. The proposal notes that specific selection criteria may be set out for certain areas of law. ${ }^{211}$ States may wish to include a provision in the governing statute of the proposed court structure that sets forth requirements of expertise in the international agreements that govern intellectual property. Given the need to balance multiple interests when interpreting standards of protection for intellectual property rights, the statute for the proposed court structure may also include requirements of familiarity with ruling on issues of administrative law. ${ }^{212}$

To ensure that adjudicators hearing disputes that involve international intellectual property rules have the relevant subject matter expertise, the process for appointing adjudicators to each dispute should not be random. The procedure for composing WTO Panels offers a point of reference. WTO Panels are composed ad hoc for each dispute and consist of three individuals, unless the parties agree to five individuals pursuant to Article 8.5 of the Dispute Settlement Understanding (DSU). ${ }^{213}$ The Secretariat proposes the candidates for the Panel to the disputing parties. The Secretariat may select candidates from a list of individuals that the Secretariat maintains, which is comprised of individuals that WTO members have nominated, or it may propose other qualified candidates that meet the requirements of DSU Articles 8.1 and 8.2..$^{214}$ DSU Article 8.6 prohibits parties from opposing the Secretariat's proposed candidates except for compelling reasons, although in practice, parties often oppose and the Secretariat then proposes alternate candidates. ${ }^{215}$

A selection process similar to that of the WTO Panels would allow disputing parties in investor-state arbitration to ensure that the panel of adjudicators hearing the dispute includes individuals with expertise in the relevant international rules governing intellectual property. The selection procedure may be a middle ground between the ad hoc nature of the current ISDS system and the random selection

209. Daniel J. Gervais, Investor-State Dispute Settlement: Human Rights and Regulatory Lessons from Lilly v. Canada, 8 U.C. IRVINE L. REV. 459, 496 (2018).

210. Id. Some states further expressed the concern that "arbitrators [do] not regard themselves as under a general duty towards an international system of justice." U.N. Doc. A/CN.9/964, supra note 2, $\mid$ 35 .

211. U.N. Doc. A/CN.9/WG.III/WP.159/Add.1, supra note 117, ๆ 20.

212. BUNGENBERG \& REINISCH, supra note 112 , at 40.

213. Marrakesh Agreement Establishing the World Trade Organization, DSU, Dispute Settlement Rules: Understanding on Rules and Procedures Governing the Settlement of Disputes, Annex 2, art. 8.5, Apr. 15, 1994, 1869 U.N.T.S. 401, 33 I.L.M. 1226 [hereinafter DSU].

214. Id. art. 8.4

215. Id. art. 8.6. 
process in the proposed multilateral court structure. The governing statute for the proposed multilateral investment court could require the list of full time adjudicators to include a minimum number of individuals with subject matter expertise in the international agreements governing intellectual property. Disputing parties may then compose the panel of adjudicators for the dispute by selecting from the list of individuals.

The issue remains, however, that allowing private investors to invoke the intellectual property provisions of international agreements may undermine the aims of the agreements. As no rule of binding precedent exists, adjudicators are not required to follow the reasoning of the decisions from the international agreement's designated dispute settlement forum. The adjudicators in ISDS may adopt different interpretative approaches than that of the designated dispute settlement forum. Some bilateral investment treaties expressly state that the purpose of the treaty is to increase foreign direct investment. ${ }^{216}$ Adjudicators in ISDS may thus interpret the agreement in a manner that places more weight on protecting the rights of the investor.

\section{B. Application of Domestic Intellectual Property law}

Intellectual property rights are geographically limited, and domestic intellectual property law varies across different states depending on each state's domestic policy decisions. Scholars have commented that patentability standards, for example, are fundamentally policy decisions that aim to achieve different policy goals across different states. ${ }^{217}$ In drafting patent laws, ${ }^{218}$ different states consider different factors in answering the question of whether the inventor has provided sufficient information to the public in exchange for the patent rights. ${ }^{219}$ Patent law requires balancing multiple interests so that the patentability standards establish a desirable balance between the rights of the intellectual property holder and the rights of the intellectual property user. ${ }^{220}$ Each state makes decisions according to its national economy and public interests. ${ }^{221}$ States in both common law and civil law

216. Noble Ventures, Inc. v. Romania, ICSID Case No. ARB/01/11, Award (Oct. 12, 2005) [hereinafter Noble Ventures Award] ("While it is not permissible ... to interpret clauses exclusively in favor of investors, here such an interpretation is justified. Considering, as pointed out above, that any other interpretation would deprive Art. II(2)(c) of practical content, reference has necessarily to be made to the principle of effectiveness, also applied by other Tribunals in interpreting BIT provisions."); SGS Decision on Jurisdiction, supra note 59, 116 ("According to the preamble [the treaty] is intended 'to create and maintain favorable conditions for investments by investors of one Contracting Party in the territory of the other. It is legitimate to resolve uncertainties in its interpretation so as to favor the protection of covered investments."'); BUNGENBERG \& REINISCH, supra note 112, at 110.

217. Okediji, supra note 37 , at 1134 .

218. Ho, supra note 17, at 225 n.37 ("A patent is a "legal document granted by a country to the creator of an invention that provides the commercially valuable ability to exclude others from making or selling the patented invention within the boundaries of the patent-granting country."').

219. Okediji, supra note 37, at 1134-35.

220. Liddell \& Waibel, supra note 28, at 23; Gervais, supra note 209, at 471-72.

221. Okediji, supra note 37, at 1133; Liddell \& Waibel, supra note 28, at 9 (noting that a state may define "prior art" as technology that is known locally in order to encourage foreign investors to introduce new technology into the region). 
jurisdictions may modify intellectual property law judicially, ${ }^{222}$ and may retroactively invalidate patents for reasons such as failure to meet patentability standards. ${ }^{223}$

The main international agreements governing intellectual property recognize the close relationship between intellectual property law and domestic policy. The Paris Convention of 1883 recognizes the independent discretion of each state on matters of patent law. ${ }^{224}$ While the Paris Convention aims to ensure fairness between domestic and foreign patent applicants, it acknowledges in Article 4bis the geographical limits of patents. ${ }^{225}$ Similarly, the Patent Cooperation Treaty of 1970 allows each state to evaluate patent applications according to the state's own patent standards, even though it standardizes the procedure for filing patents across multiple states. ${ }^{226}$ More recently, the TRIPS Agreement sets forth global minimum standards of intellectual property protection while allowing states flexibility in implementing the standards through domestic intellectual property law. For example, the TRIPS Agreement leaves the definition for "invention" to the discretion of individual states. $^{227}$

In light of the close relationship between the host state's intellectual property law and its domestic policy decisions, recent discussions have suggested limiting the power that arbitral tribunals have to rule on issues relating to domestic intellectual property law. ${ }^{228}$ Scholars commented that arbitral tribunals risk disturbing the balance in the domestic patent law framework by issuing a ruling without full appreciation of the domestic law. ${ }^{22}$ Susy Frankel noted that arbitral tribunals are

222. Liddell \& Waibel, supra note 28, at 10 n.30 (noting that German courts have rejected a longstanding practice of assessing for patentability); $i d$. at 11 (noting that the concept of an "enabling disclosure" in the United Kingdom was a judicial creation). In Continental Casualty v. Argentine Republic, the tribunal stated that "it would be unconscionable for a country to promise not to change its legislation as time and needs change, or even more to tie its hands by such a kind of stipulation in case a crisis of any type or origin arose." Okediji, supra note 37, at 1135 (citation omitted).

223. Ho, supra note 17, at 245; Liddell \& Waibel, supra note 28, at 10. The United States Supreme Court modified the obviousness standard, introducing a higher threshold for patentability, in 1850 in Hotchkiss v. Greenwood. 52 U.S. 248 (1850). Ho, supra note 17, at 245-46. See also Liddell \& Waibel, supra note 28, at 14-15 (noting that a reason for allowing judicial revocation of patents is that the Patent Office receives a large number of patent applications and requiring a detailed evaluation of all of the applications would result in high costs that may overweigh the benefits).

224. Paris Convention for the Protection of Industrial Property, as last revised at the Stockholm Revision Conference, art. 4bis, Mar. 20, 1883, 21 U.S.T. 1583; 828 U.N.T.S. 305 [hereinafter Paris Convention].

225. Ho, supra note 17, at 230. Paris Convention Article 4bis(1) states that patents applied in one country "shall be independent of patents obtained for the same invention . . . in other countries." Paris Convention, supra note 224 , at art. 4 bis.

226. Ho, supra note 17 , at $228-29$ n.51.

227. Id. at 229 .

228. See Achmea B.V. v. Slovak Republic, UNCITRAL PCA Case No. 2008-13, Award on Jurisdiction, Arbitrability and Suspension, \ 282 (Oct. 26, 2010) [hereinafter Achmea Award on Jurisdiction, Arbitrability and Suspension] ("The argument that the ECJ has an 'interpretative monopoly" and that the Tribunal therefore cannot consider and apply EU law, is incorrect. The ECJ has no such monopoly. Courts and arbitration tribunals throughout the EU interpret and apply EU law daily.").

229. Gervais, supra note 209 , at 488 ("Intellectual property obligations in the investment context thus pose a new threat to states' traditional lawmaking powers by providing foreign actors a singular opportunity to challenge laws that have been enacted with the domestic public interest in full view."); 
likely to disproportionately focus on the function of intellectual property as property rights, rather than on the role of intellectual property law in rewarding innovation or on the balance between intellectual property rights and public interests such as the affordability of medicines. ${ }^{230}$

States have taken steps to define the scope of arbitral tribunals' power in ruling on issues relating to domestic intellectual property law. Canada and the European Union appended a declaration to CETA to clarify that domestic courts have the power to decide matters relating to intellectual property rights and that states are free to determine the method of implementing the provisions on intellectual property. ${ }^{231}$ Further, CETA states that tribunals may only review domestic law as a matter of fact and must follow the prevailing interpretation of the domestic law given by the state's domestic courts. $^{232}$

The proposal for the multilateral investment court does not specify the procedure for determining the applicable substantive law. Arbitral tribunals currently determine the applicable substantive law using either the treaty's choice of law provision or the arbitral institution's rules of procedure. ICSID Convention Article 42 states that the applicable substantive law is that to which the parties have agreed, or, in the absence of such agreement, the host state's domestic law and the applicable public international law. ${ }^{23}$ The original practice was to first apply the host state's domestic law and then apply public international law only to supplement the domestic law. ${ }^{234}$ More recent arbitral decisions suggest, however, that tribunals may accord equal weight to domestic and international law for certain issues, such as expropriation and the denial of justice. ${ }^{235}$

Liddell \& Waibel, supra note 28, at 23-24; see also Petersmann, supra note 200, at 44 (“[C]onstitutional and fundamental rights of citizens entail governmental duties to regulate market competition, for instance by protecting consumers against their individual weaknesses, cognitive constraints and bounded rationality so that public health protection can 'take precedence over economic considerations."').

230. Gervais, supra note 209, at 486 (quoting Susy Frankel, Interpreting the Overlap of International Investment and Intellectual Property Law, J. INT'L ECON. L. 1, 5 (2016)).

231. Liddell \& Waibel, supra note 28, at 4 n.6 ("'TT]he domestic courts of each Party are responsible for the determination of the existence and validity of intellectual property rights ... each Party shall be free to determine the appropriate method of implementing the provisions of this Agreement regarding intellectual property within their own legal system and practice.").

232. CETA, supra note 135, art. 8.31 - 2 .

233. ICSID Convention, supra note 76, art. 42 ("The Tribunal shall decide a dispute in accordance with such rules of law as may be agreed by the parties. In the absence of such agreement, the tribunal shall apply the law of the Contracting State party to the dispute (including its rules on the conflict of laws) and such rules of international law as may be applicable.").

234. Id.

235. Wena Hotels Ltd. v. Arab Republic of Egypt, ICSID Case No. ARB/98/4, Decision on Annulment, 40 (Feb. 5, 2002) [hereinafter Wena Decision on Annulment] ("The law of the host State can indeed be applied in conjunction with international law if this is justified. So too international law can be applied by itself if the appropriate rule is found in this other ambit."); Amco v. Indonesia, ICSID Case No. ARB/81/1, R, Award in Resubmitted Proceeding, 40 (May 31, 1990) [hereinafter Amco Award in Resubmitted Proceeding] ("If there are no relevant host-state laws on a particular matter, a search must be made for the relevant international laws. And, where there are applicable host-state laws, they must be checked against international laws, which will prevail in case of conflict. Thus international law is fully applicable and to classify its role as 'only' 'supplemental and corrective' seems a distinction without a difference.”); BUNGENBERG \& REINISCH, supra note 112, ๆ 112. 
States may wish to consider including a choice of law provision in the governing statute for the proposed multilateral investment court. The provision would state whether investors must choose between domestic and international remedies. If the provision requires the exhaustion of domestic remedies, it would obligate the investor to file claims in the domestic court first. If the investor then files the claims in investor-state arbitration, the adjudicators in ISDS would have the guidance of the domestic court's views. A provision that requires investors to waive their right to seek remedy in domestic courts after having submitted a claim in investor-state arbitration would similarly encourage investors to first seek redress before domestic courts. Such a provision may also aid in lowering the cost of ISDS proceedings by preventing parallel proceedings.

Limiting the standard of review of domestic courts' decisions on issues relating to domestic intellectual property law would give deference to domestic courts on these issues. ${ }^{236}$ Limiting the standard of review to the denial of justice would require investors to exhaust local remedies before filing a claim in investor-state arbitration. ${ }^{237}$ The provision would allow adjudicators in ISDS to find a breach of the FET standard only when the domestic court's decision contradicts settled intellectual property law. Investors would not have a legitimate expectation that patents are irrevocable or that domestic patent law must remain unchanged over time. ${ }^{238}$ In this way, the standard of review ensures that investor-state arbitral decisions do not overrule domestic courts' decisions on the grounds that a more rational set of reasons was available to the domestic court. ${ }^{239}$

\section{Regulatory Space for Domestic Intellectual Property Policy}

Investor-state disputes that involve issues relating to domestic intellectual property law may pose constraints to the host state's regulatory space for intellectual property policy. ${ }^{240}$ A large arbitral award against the host state may limit the state's ability to fulfill its other developmental or international commitments. ${ }^{241}$ In July 2014 , the tribunal in the Yukos cases awarded over $\$ 50$ billion against Russia. ${ }^{242}$ As of 2015 , more than 100 pending actions were worth over $\$ 1$ billion in potential award. ${ }^{243}$ The financial burden is particularly heavy for developing states, who are

236. Liddell \& Waibel, supra note 28, at 1,17-18. CETA currently states that "the domestic courts of each Party are responsible for the determination of the existence and validity of intellectual property rights." Gervais, supra note 209, at 502.

237. Id. at 18

238. Id. at 1 .

239. Id. at $18-19$.

240. Okediji, supra note 37, at 1122. See also World Investment Report 2015, supra note 6, at 126 (noting inconsistencies between states' obligations under international investment agreements and under other international agreements).

241. Gervais, supra note 209, at 502-04. See also Adam H. Bradlow, Human Rights Impact Litigation in ISDS: A Proposal for Enabling Private Parties to Bring Human Rights Claims Through Investor-State Dispute Settlement Mechanisms, 43 YALE J. INT'L L. 355, 364 (2018) (noting that states sometimes comply with corporations' demands in order to avoid risking losses in arbitration).

242. Ho, supra note 17, at 233.

243. Id. at 219 . 
respondents in seventy percent of the disputes as of 2014. ${ }^{244}$ The mere possibility of a large award may discourage host states from modifying their domestic intellectual property law, even when the modifications comply with the states' international obligations. $^{245}$

With the emergence of ISDS as a forum for investors to enforce the host state's intellectual property obligations, states may face a greater number of challenges to their intellectual property laws, as the same political considerations that impede states from bringing certain claims do not apply to private parties. ${ }^{246}$ Investors may bring claims under the FET standard to challenge new intellectual property laws. These claims can affect host states' decisions to implement new intellectual property laws, such as India's law prohibiting the granting of patents for drugs that are similar to existing drugs without proof of improved efficacy. ${ }^{247}$ This section of India's intellectual property law defines the patentability requirements of "invention" and "new."248 It is similar to the Canadian promise doctrine that Eli Lilly challenged. Both laws aim to ensure that the patentee has contributed sufficient information to the public in exchange for patent rights. Although states have not brought claims against India in the WTO dispute settlement system, investors may choose to challenge the law in investor-state arbitration under the FET standard. ${ }^{249}$ Such claims may discourage other states from adopting similar laws. ${ }^{250}$

While the state's signature to the investment treaty represents consent to the investor-state dispute settlement system, the broad nature of the treaty language and inconsistencies in arbitral decisions give rise to claims that are unanticipated at the time of the treaty's signing. ${ }^{251}$ For example, past arbitral decisions suggest that foreign investors may be able to claim an intellectual property right that is not available to domestic individuals. In Saipem S.p.A. v. Bangladesh, the tribunal rejected Bangladesh's argument that the definition of "investment" under the bilateral investment treaty should be the same as that under Bangladeshi law, which does not include certain intellectual property rights. ${ }^{252}$ The ruling of the Saipem tribunal suggests that foreign investors would be able to enforce certain intellectual property rights that are not available to Bangladeshi citizens.

The scope of the state's right to regulate in relation to the investor's legitimate interest in the host state's investment environment under the FET standard remains ambiguous. ${ }^{253}$ The tribunal in Saluka v. Czech Republic recognized "the host State's

244. World Investment Report 2015, supra note 6, at 146.

245. Ho, supra note 17, at 216.

246. Id. at 284-85.

247. Id. at 283 .

248. Id. at $284-85$.

249. Id.

250. Id

251. Ho, supra note 17, at 235.

252. Saipem S.p.A. v. The People's Republic of Bangl., ICSID Case No. ARB/05/07, Award (June 30, 2009). See also Okediji, supra note 37, at 1133 (citation omitted). The tribunal in Saipem S.p.A.v. Bangladesh stated that upholding "Bangladesh's approach ... would lead to a different interpretation and thus a different scope of protection under the BIT depending on the country in which the investment is made." Id.

253. Grosse Ruse-Khan, Litigating Intellectual Property Rights, supra note 158, at 21. 
right ... to regulate domestic matters in the public interest," holding that "[n]o investor may reasonably expect that the circumstances prevailing at the time [that] the investment is made remain totally unchanged." In Saluka, the tribunal found that Romania's new law impacting all owners of duty-free operations did not violate the FET standard because it did not disproportionately or discriminatorily impact the claimant's investments. ${ }^{254}$ Other tribunals recognized a need to weigh the host state's right to regulate against the investor's legitimate interest. ${ }^{255}$ Past arbitral decisions suggest that the standard for weighing the interests may impose stringent constraints on the host state's regulatory space. In Tecmed, the tribunal found that a valid public interest cannot outweigh the investor's legitimate interests unless the state action is necessary to achieve the public interest. ${ }^{256}$ The tribunal defined "necessary" as being either the only measure available to the host state to achieve the public policy objective or the least detrimental measure of a number of options. ${ }^{257}$ The tribunal in Tecmed found that the host state's refusal to renew a license for a hazardous waste treatment plant constituted indirect expropriation because, even though the objective of resolving local complaints concerning health and safety was a legitimate public interest, other less detrimental solutions, such as relocating the plant, existed. ${ }^{258}$

States have attempted to clarify the scope of the host state's right to enact measures that further the state's legitimate policy objectives. The 2012 U.S. Model BIT lists the protection of public health, safety, and the environment as legitimate policy objectives. ${ }^{259}$ It states that, "[e]xcept in rare circumstances, nondiscriminatory regulatory actions by a Party that are designed and applied to protect legitimate public welfare objectives, such as public health, safety and the environment, do not constitute indirect expropriations." ${ }^{260}$ Similarly, Article 23.2 of CETA identifies public policy goals relating to labor protection as having priority

254. Ho, supra note 17, at 282. The tribunal in Saluka set forth four factors to the FET standard: (1) the host state's implementation of reasonably justifiable public policies; (2) the host state's compliance with requirements of consistency, transparency, fairness, and nondiscrimination; (3) whether the host state treated foreign investors based on unreasonable distinctions and demands; and (4) whether the host state's actions can be justified with reasonable relationship to rational policies not motivated by preference for other investments over the investor's investment. Grosse Ruse-Khan, Litigating Intellectual Property Rights, supra note 158, at 21.

255. See S. Am. Silver Ltd. (Bermuda) v. Plurinational State of Bolivia, PCA Case No. 2013-15, Award, 9ๆ 647-649 (Nov. 22, 2018) [hereinafter South American Silver Award] (stating that investment tribunals have "recognized that the commitment of the State to afford fair and equitable treatment to foreign investments does not entail relinquishing their regulatory powers in the public interest or the need to adapt their legislation to changes and emerging needs."). The tribunal noted that the FET standard requires a "weighing of the legitimate interests of the foreign investor with the legitimate interests of the host State and others, including (in particular) its own citizens and residents." Id. $\uparrow 649$.

256. Ho, supra note 17, at 269. In Methanex, the tribunal found that a law prohibiting the use of a petrol additive deemed to be carcinogenic was a regulation that served legitimate public interests and therefore not compensable for expropriation. Methanex Final Award, supra note 167, Part IV, Chapter $\mathrm{D}, \boldsymbol{\uparrow} 15$.

257. Ho, supra note 17 , at 269 .

258. Id.

259. Id. at 267 .

260. Gervais, supra note 209, at 24. 
over trade. ${ }^{261}$ The Association Agreement between the European Union and Central America also requires, in Article 291(2), that host states fulfill their labor and environmental obligations. ${ }^{262}$

Allowing joint interpretation may help to address the uncertainties that host states face about whether certain policy objectives relating to intellectual property may take priority over the investor's legitimate interests under the FET standard. Joint interpretation requires adjudicators to consider the treaty parties' subsequent agreements when interpreting the treaty language. It allows the treaty's interpretation to evolve in response to unanticipated circumstances that arise after the signing of the treaty and contributes to maximizing the joint value of the treaty at the time of performance. ${ }^{263}$ As a general principle of international treaty interpretation, Article 31(3)(a) of the Vienna Convention on the Law of Treaties (VCLT) requires adjudicators to "take[] into account.... any subsequent agreement $[\mathrm{s}]$... [between the treaty parties] regarding the interpretation of the treaty or the application of its provisions." 264 Under VCLT 31(3), the treaty parties' subsequent agreements are not necessarily binding. ${ }^{265}$ While the VCLT addresses the effect of subsequent agreements on third-party states, it does not address the effect of the agreements on private third parties. ${ }^{266}$ States may wish to include in the statute for the proposed multilateral investment court a provision that requires subsequent agreements to be binding on all parties to the dispute. ${ }^{267}$

261. CETA, supra note 135, art. 23.2 ("[E]ach Party shall seek to ensure those laws and policies provide for and encourage high levels of labour protection and shall strive to continue to improve such laws and policies with the goal of providing high levels of labour protection.").

262. Agreement Establishing an Association Between Central America, on the One Hand, and the European Union and Its Member States, on the Other, art. 291(2), 2012 O.J. (L 346) 3 [hereinafter E.U.Central America Association Agreement] ("A Party shall not waive or derogate from, or offer to waive or offer to derogate from, its labour or environmental legislation in a manner affecting trade or as an encouragement for the establishment, acquisition, expansion or retention of an investment or an investor in its territory.").

263. From a contract theory perspective, complete treaties are impossible to draft because the treaty parties cannot foresee all possible future outcomes. Parties aim to draft treaties that both maximize jointly beneficial investments ex ante and maximize the value at the time of performance. The treaty must thus balance the hard terms, which ensure credible commitments, with the flexibility to respond to unforeseen circumstances. The need to balance ex ante commitment terms with ex post flexibility in interpretation is particularly important in long-term agreements. Anne van Aaken, Delegating Interpretative Authority in Investment Treaties: The Case of Joint Administrative Commissions, in RESHAPING THE INVESTOR-STATE Dispute SeTtlement System 21, 25-26 (Jean E. Kalicki \& Anna Joubin-Bret eds., 2015).

264. Vienna Convention on the Law of Treaties (VCLT) art. 31(3)(a), opened for signature May 23, 1969, 1155 U.N.T.S. 331 [hereinafter Vienna Convention]. The VCLT Drafting Committee emphasized that the subsequent agreement need not be in the same form as the initial treaty. David Gaukrodger, The Legal Framework Applicable To Joint Interpretive Agreements of Investment Treaties, at 7 n.14, OECD Working Papers on International Investment 2016/01 (2016).

265. Gaukrodger, supra note 264, at 9-10.

266. Id. at 11 (noting that Roberts proposed a framework, focusing on the reasonableness of the subsequent interpretation compared to other possible interpretations and on the timing of the subsequent interpretation, for evaluating whether treaty parties' subsequent agreements should be applicable to private covered parties).

267. The VCLT Commission noted that one manner in which subsequent agreements may be binding is for the treaty itself to provide for the possibility. $I d$. at 10 . 
A provision that requires the expert agencies of both the host state and the investor's home state to review issues relating to intellectual property law may protect the investor from opportunistic state measures while, at the same time, contributing to expediency in resolving the dispute. ${ }^{268}$ The 2012 U.S. Model BIT and the 2004 Canadian Foreign Investment Promotion and Protection Agreement both include such a provision for issues relating to financial market and taxation measures. ${ }^{269}$ The 2012 U.S. Model BIT delegates the judgment of issues relating to the nationalization of foreign bank subsidiaries to the expert authorities of the host state and the investor's home state. ${ }^{270}$ It prohibits the investor from filing a suit with an arbitral tribunal if the expert agencies of both countries agree that no expropriation has occurred. ${ }^{271}$ The provision may serve as a point of reference for drafting a similar provision that requires a joint expert commission's review of intellectual property issues in investor-state disputes.

\section{CONCLUSION}

This Article explored whether a multilateral investment court could address the issues that arise from the intersection of investment law with intellectual property law. This Article analyzed the role of the European Commission's proposed multilateral investment court in addressing the concerns with the present ISDS system. In doing so, this Article showed that the issues that are present in investorstate disputes that involve intellectual property law are distinct from the issues that have been at the center of discussions about potential reform options for the ISDS system.

The emergence of investor-state arbitration as a forum for investors to seek protection for their intellectual property rights presents issues that arise from the arbitral tribunal's role in disputes that involve intellectual property law. The interpretive approach that arbitrators adopt in applying the intellectual property provisions of an international agreement may differ from that of the designated dispute settlement forum for the international agreement. Investor-state disputes that involve issues of domestic intellectual property law may impose constraints on the host state's regulatory space for policies relating to intellectual property. In light of these issues, this Article proposed additional considerations for the multilateral investment court structure. This Article considered the potential benefits and drawbacks of a multilateral investment court in the context of the intersection of investment law and intellectual property law. As such, this Article serves to invite new dialogues in the broader discussion of the reform of the investor-state dispute settlement system.

268. See Van Aaken, supra note 263, at 45 (noting that delegating the decision-making process to independent, nonpolitical agencies would mitigate the problem of possibly politicizing the dispute settlement process).

269. Id. at $22-23$.

270. 2012 U.S. Model BIT, supra note 180, art. 20(3).

271. Id. 